\title{
The New Graphene Family Materials: Synthesis and Applications in Oxygen Reduction Reaction
}

\author{
Xin Tong ${ }^{1,2}$, Qiliang Wei ${ }^{2}$, Xinxing Zhan ${ }^{1}$, Gaixia Zhang ${ }^{2}$ and Shuhui Sun ${ }^{2, *}$ \\ 1 Key Lab for Functional Materials Chemistry of Guizhou Province, School of Chemistry and Material Science, \\ Guizhou Normal University, Guiyang 550001, China; xin.tong@emt.inrs.ca (X.T.); \\ zhanxinxing@hotmail.com (X.Z.) \\ 2 Institut National de la Recherche Scientifique (INRS), Énergie, Matériaux et Télécommunications, \\ 650 Boulevard Lionel-Boulet, Varennes, QC J3X 1S2, Canada; qiliang.wei@emt.inrs.ca (Q.W.); \\ gaixia.zhang@emt.inrs.ca (G.Z.) \\ * Correspondence: shuhui@emt.inrs.ca; Tel.: +1-514-228-6919; Fax: +1-450-929-8102
}

Academic Editors: Maria Jesús Lázaro and Maria Victoria Martínez Huerta Received: 1 November 2016; Accepted: 19 December 2016; Published: 23 December 2016

\begin{abstract}
Graphene family materials, including graphene quantum dots (GQDs), graphene nanoribbons (GNRs) and 3D graphene (3D-G), have attracted much research interest for the oxygen reduction reaction (ORR) in fuel cells and metal-air batteries, due to their unique structural characteristics, such as abundant activate sites, edge effects and the interconnected network. In this review, we summarize recent developments in fabricating various new graphene family materials and their applications for use as ORR electrocatalysts. These new graphene family materials play an important role in improving the ORR performance, thus promoting the practical use in metal-air batteries and fuel cells.
\end{abstract}

Keywords: ORR; graphene quantum dots; graphene nanoribbons; 3D graphene

\section{Introduction}

Fuel cell technology is regarded as one of the most promising clean energy solutions to solve the main challenges that humanity currently faces, including environmental pollution, resource depletion and global warming, since it generates electricity with the by-products of only water and heat [1-5]. In fuel cells, highly efficient electrocatalyst to facilitate the kinetically sluggish oxygen reduction reaction (ORR) is crucial to convert the chemical energy of the fuel $\left(\mathrm{H}_{2}\right.$ or liquid alcohol) directly into electricity. In both acidic and alkaline electrolytes, the ORR usually occurs through two pathways: the two-electron $\left(2 \mathrm{e}^{-}\right)$process by the reduction of $\mathrm{O}_{2}$ to $\mathrm{H}_{2} \mathrm{O}_{2}$ and the four-electron $\left(4 \mathrm{e}^{-}\right)$process by the direct reduction of $\mathrm{O}_{2}$ to $\mathrm{H}_{2} \mathrm{O}[6,7]$. The ORR on platinum-based (Pt-based) electrocatalysts, which are the most used commercial catalysts, can usually be conducted through the $4 \mathrm{e}^{-}$pathway with high onset potential and high current density. However, the development and wide-spread commercialization of fuel cells are largely hampered by the Pt-based catalysts due to their high cost, limited resources and CO poising sensitivity. Therefore, developing low-cost and high-performance alternatives, such as non-precious metal and metal-free electrocatalysts, to replace the expensive Pt-based catalysts has become the hot topic in the fuel cell community [8-10].

In recent years, two-dimensional (2D) graphene-based materials have emerged as new types of electrocatalysts due to their excellent conductivity, high specific surface area (SSA) and tailorable surface chemistry, as summarized in previous excellent reviews $[4,8,11,12]$. Although the large SSA and high electrical conductivity of pristine graphene are supposed to be useful for the electrocatalysis process, in practice, with the strong van der Waals interactions and $\pi-\pi$ stacking between graphene layers, the 2D graphene nanosheets could easily restack and aggregate, which significantly diminish 
the SSA, hinder the rapid electron transport and, therefore, consequently limit its utilization. Moreover, the limited number of active sites at the edges of pristine graphene restricts its practical applications. Therefore, the forefront of this research domain has been shifted to the exploration of chemically-modified graphene (CMG), such as functionalized or heteroatom-doped graphene, nanoparticles/graphene composites and dimension-tailored graphene nanostructures $[4,5,13-15]$. Generally, the methodology for the chemical modification of graphene can be divided into two categories, including non-covalent interactions and covalent bonding [16]. The former is usually achieved by employing electrostatic interaction, $\pi-\pi$ stacking interactions, hydrogen bonding and van de Waals force. In contrast, the covalent bonding can change the structure of graphene via heteroatom-doping. These materials can be prepared either via in situ doping during synthesis [17] or through post-treatment with heteroatom-containing precursors [18].

It is believed that graphene is the basic unit for all other graphitic materials, such as graphene can stack layer by layer into graphite, roll into carbon nanotubes (CNTs) and wrap up into fullerene [19]. Moreover, the 2D graphene can also be used as building blocks for a series of novel graphene-based nanostructures [20,21]. As shown in Figure 1, graphene can be cut into small pieces: graphene quantum dots (GQDs); split into small slices: graphene nanoribbons (GNRs); and scaffolded into 3D architectures: 3D graphene (3D-G). Since the intrinsic properties of graphene are almost maintained in these new structures, they are defined as graphene family materials. Further, the graphene family materials also possess some unique electrochemical properties compared with the pristine graphene. As shown in Figure 2a,b, due to the lateral (usually $<100 \mathrm{~nm}$ ) and the thickness (in single and few layers $(<10)$ ), GQDs are all nanometer-sized; the edge effects and properties associated with the quantum confinement are found in numerous articles [22-24]. The thin elongated morphology of GNRs is shown in Figure 2c-e. The GNRs can be regarded as a quasi-1D material because of the much shorter dimension than the other one in the plane. Because of their unique structure, the GNRs possess some unique features, such as abundant edges, a high length-to-width ratio and numerous activate sites [25-27]. In Figure $2 \mathrm{f}-\mathrm{h}$, an interconnected $3 \mathrm{D}$ porous structure was constructed by physical cross-linking of randomly-oriented wrinkled paper-like graphene sheets; the pore sizes could range from several hundred nanometers to several micrometers. In a macroscopic view, the 3D-G shows a certain shape morphology (e.g., cylindrical structure in most references) with strong mechanical strength. It is noted that these 3D-G structures are reported in the literature with different names, such as graphene foams [28], graphene hydrogels [29], graphene sponges [30], graphene aerogels [31] and porous grapheme [32]. In this review, the minor differences in their structural morphologies and properties are neglected, and herein, such materials are all called 3D-G. All of these 3D networks present similar properties, such as high SSA, low density, strong mechanical strength, excellent flexibility, high conductivity and fast mass and electron transport kinetics. Obviously, these porous 3D-G structures could prevent the aggregation of graphene nanosheets, which guarantees fast electron and mass transport and adequate activate sites, thus enhancing their ORR performances in applications.

In this review, we focus on the recent progress in the controlled fabrication of graphene family materials (from 0D quantum dots, to 1D nanoribbons and to 3D network-structured monoliths) and their application in ORR. It begins with an introduction of the synthetic strategy of graphene family materials and their derivatives. Then, the promising potential applications of these materials for ORR are discussed. Finally, we present the overview and perspectives on the features and functions of different dimensional graphene family materials, from 0D to 3D. 


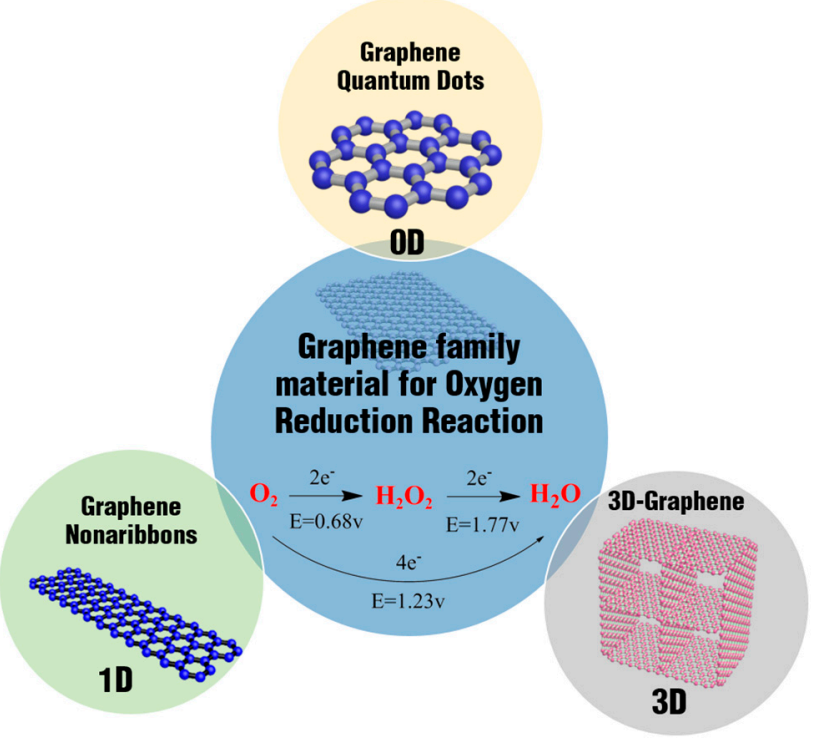

Figure 1. Schematic of graphene family materials of various dimensions for oxygen reduction reaction (ORR).
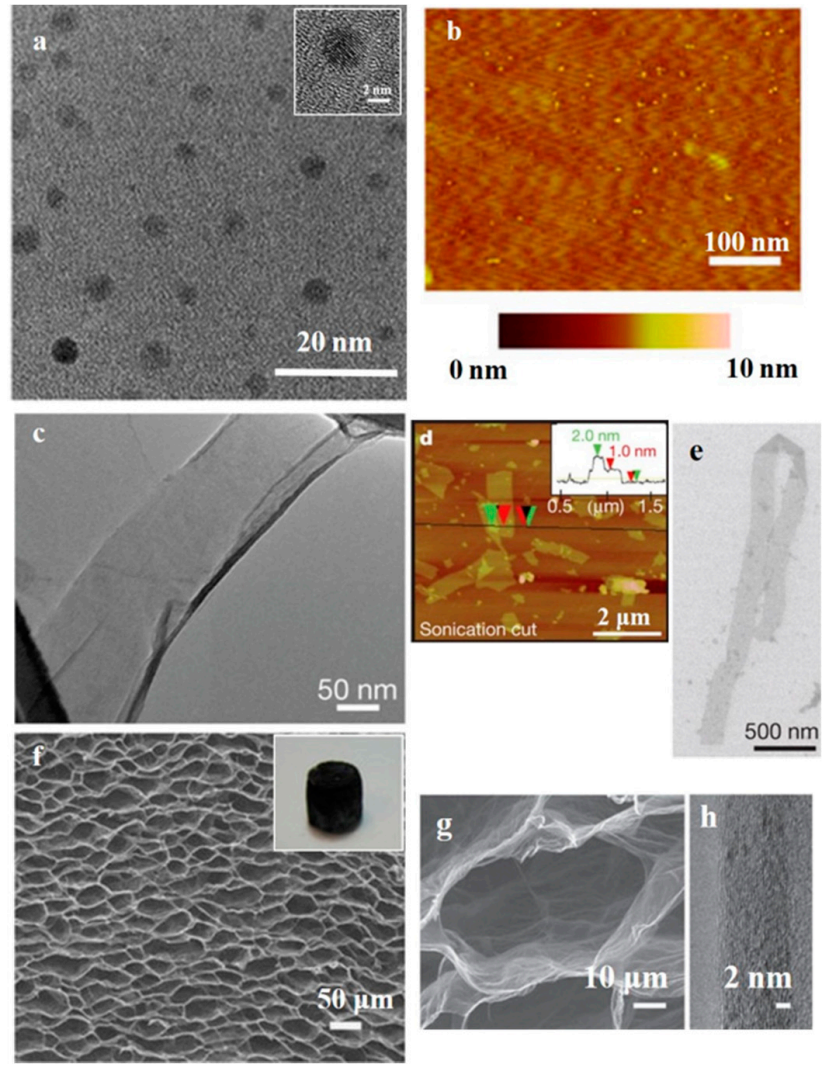

Figure 2. (a) TEM image and (b) atomic force microscopy (AFM) image of graphene quantum dots (GQDs). Reprinted by permission from Macmillan Publishers Ltd: Nature Communications [33]. Copyright 2013. (c) TEM image, (d) AFM image and (e) SEM image of graphene nanoribbons (GNRs). Reprinted by permission from Macmillan Publishers Ltd: Nature [34]. Copyright 2009. $(\mathbf{f}, \mathbf{g})$ SEM images and (h) TEM image of 3D graphene (3D-G). A Photo of 3D-G is presented in the inset in (f). Reprinted by permission from Macmillan Publishers Ltd: Nature Communications [35]. Copyright 2012. 


\section{The Synthetic Strategy of Graphene Family Materials}

To get a unique advantageous architecture and excellent performance, the fabrication technologies of graphene family materials with controlled thickness, size and morphology are highly desired. In the following section, we will review the main approaches of constructing graphene family materials with different dimensions, i.e., 0D GQDs, 1D GNRs and 3D-G. Similar to the production of graphene, the synthetic strategies of GQDs and GNRs can be divided into two main categories: (i) the top-down method; and (ii) the bottom-up method, as shown in Figure 3. For 3D-G, there are three main strategies: (i) the chemical self-assembly method; (ii) the template-assisted chemical method; (iii) the template-assisted chemical vapor deposition (CVD) method.

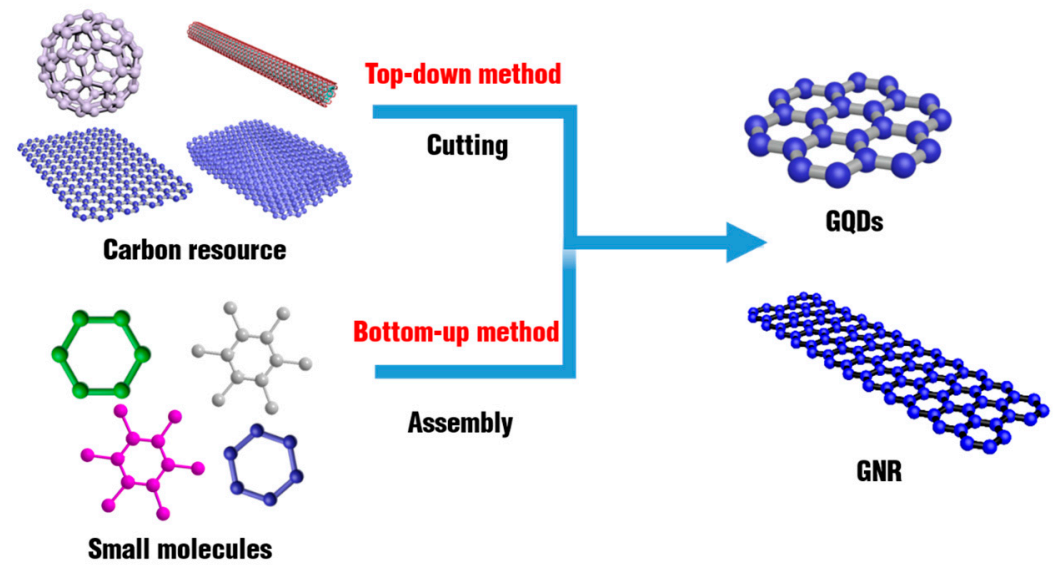

Figure 3. Schematic diagram of the top-down and bottom-up methods for synthesizing GQDs and GNRs.

\subsection{Quasi-OD Graphene Quantum Dots}

The main characteristics of GQDs are that the side and thickness are all nanometer-sized. Therefore, the key for preparing GQDs is to precisely control the size and thickness [22-24,36,37].

\subsubsection{Top-Down Method}

Generally, the graphitic materials, such as carbon nanotubes (CNTs) [38,39], carbon fiber [40], grapheme oxide (GO) [41], grapheme [36], graphite [42] and other materials [43-45], are usually used as the carbon source to produce GQDs. Chemical acid oxidation $[41,46,47]$, the electrochemical approach $[38,48,49]$, the hydrothermal or solvothermal cutting method [50-52] and the physical method $[53,54]$ are employed to synthesize GQDs.

The most popular top-down method is to employ the chemical techniques to prepare GQDs [55]. GO is regarded as the most promising candidate to fabricate GQDs, because of its high solubility in aqueous solution, ease for large-scale production and surface modification. The oxygen-containing groups on GO surfaces play the vital role in the defect-mediated fragmentation processes $[36,50]$. For example, Pan and his group first prepared water-soluble GQDs with sub-10-nm sizes by hydrothermal cutting of GO [50]. The diameters of GQDs are mainly between 5 and $13 \mathrm{~nm}(9.6 \mathrm{~nm}$ on average), and the thicknesses are in the range of 1-2 $\mathrm{nm}$ (1-3 graphene layers). During the hydrothermal deoxidization process, the linear defects on the thermally-reduced GO, which is composed of fewer epoxy groups and more carbonyl groups, may further break up by the remove of bridging $\mathrm{O}$ atoms, thus forming GQDs eventually.

In brief, these top-down methods are simple and easy for scale up. However, the precise control of the size and morphology of GQDs is hardly achieved, and the isolation and purification of the final products are complicated. 


\subsubsection{Bottom-Up Method}

Like graphene, GQDs are composed of carbon atoms that are arranged in six-membered, hexagonal rings. Therefore, GQDs can also be synthesized by stepwise solution chemistry of alicyclic compounds [56]. In the Li group, the large colloidal GQDs with uniform and tunable sizes were obtained by oxidative condensation reactions [57]. The combining process of graphene moieties can be achieved by the oxidation of polyphenylene dendritic precursors. Then, silica gel chromatography was used to purify the products. The number of carbon atoms in GQDs can be easily controlled. Furthermore, the redox potentials can be tuned by chemical functionalization. A series of GQDs that contains 132, 168 and 170 carbon atoms can be obtained. Then, they used a shield strategy to reduce the attraction between graphene layers and the tendency of forming insoluble aggregates [58]. This solution-chemistry approach can easily control the chemical nature and geometry of the edges, which are important to determine their electrochemical properties.

These bottom-up methods offer exciting opportunities to get a high degree of control over the size, shape, morphology and, thus, properties. Yet, these methods require complicated multi-step synthesis, and the sizes of as-obtained GQDs are usually very small (less than $5 \mathrm{~nm}$ ).

\subsection{Quasi-1D Graphene Nanoribbons}

GNRs can be seen as the narrow and straight slices of graphene, particularly the width of GNRs is much shorter than the length. Like the GQDs, the methods to prepare GNRs can also be divided into two kinds: (i) top-down; and (ii) bottom-up methods, as shown in Figure 3.

\subsubsection{Top-Down Method}

Usually, the GNRs can be obtained by unzipping CNTs [34,59-63], cutting graphene [64-66] and cracking graphite $[67,68]$. Among them, employing the CNTs as the source to get the GNRs is mostly used in the literature because of the mature and large-scale availability of CNTs. Much effort has been dedicated to longitudinal unzipping of the CNTs, such as selective etching [59,61], chemical attacking $[34,60,62,63]$, nanoparticle cutting $[69,70]$ and metal atom intercalation $[71,72]$. In the team of James M. Tour, a simple solution-based oxidative approach using $\mathrm{KMnO}_{4}$ and $\mathrm{H}_{2} \mathrm{SO}_{4}$ was developed [34]. The GNRs consist of 1-30 graphene layers, with lengths up to $4 \mathrm{~mm}$ and width of 100-500 nm. Meanwhile, an Ar plasma etching method using a polymer film as an etching mask to unzip the MWCNTs is proposed by Dai et al. [59]. The GNRs are $10-20 \mathrm{~nm}$ in width and consist of single-, bi- and tri-layer graphene. A potassium intercalation method is also used to longitudinally split the CNTs by James M. Tour [73]. Parashar et al. reported a catalytic unzipping of CNTs method, based on the solubility of carbon atoms in nickel, to synthesize GNRs [70]. The GNRs are about 20-22 $\mathrm{nm}$ in width and consist of a single layer to a few layers of graphene.

Cutting the 2D graphene sheets is also a feasible and convenient strategy to obtain 1D GNRs [65,66]. Han et al. used a lithographical pattern method to get GNRs [64]. After the E-beam pattering process on mechanically-exfoliated graphene to form an etch mask defining nanoribbons, an oxygen plasma etching method is used to fabricate GNRs. With the adjusting of hydrogen silsesquioxane, the width of GNRs can be tuned. When the 3D graphite is used, the thickness and the width should all be decreased. A so-called diamond-edge-induced nanoscale cutting method was applied to produce the GNRs by Mohanty et al. [68]. Firstly, the graphite nano-blocks with a certain width were obtained by cutting along the direction perpendicular to the graphitic planes of the highly oriented pyrolytic graphite (HOPG). Subsequently, the superacid-based-exfoliation process is used to get GNRs with high structural control in 5-nm resolution.

This top-down strategy is very promising for large-scale GNR production. It is worth continually exploring and optimizing the separation and purification process. 


\subsubsection{Bottom-Up Method}

On the other hand, a bottom-up approach based on organic precursors or CVD could be exploited to get GNRs with precise control at the molecular level [74].

The GNRs were synthesized by a solution-based polymerization of pre-prepared molecular precursors followed by cyclodehydrogenation by Timothy et al. [75]. The GNRs are $1 \mathrm{~nm}$ in width and $>100 \mathrm{~nm}$ in length with atomically-smooth armchair edges. Impressively, over $1 \mathrm{~g}$ GNRs could be obtained in a one-pot synthesis. Furthermore, CVD was also a good way to synthesize GNRs [76,77]. Wei et al. developed a ZnS-ribbon-template CVD method to produce GNRs in methane decomposition [76]. The ZnS template could be removed by acid treatment after synthesis, and then, GNRs/Si are obtained. The thickness of GNRs can be controlled by the growth time (4, 8 and $20 \mathrm{~min})$ and the gas flow rate $\left(30,60,100\right.$ and $\left.200 \mathrm{sccm} \mathrm{CH}_{4}\right)$, and the width and length can be tuned by adjusting the size of the $\mathrm{ZnS}$ ribbon template. In other words, both the scalable production and control of the morphologies can be achieved by the template CVD method.

Unlike the top-down method mentioned above, bottom-up strategies starting from molecular precursors could realize the scalable production of GNRs at the molecular level [74]. Additionally, the GNRs prepared by CVD could exhibit a good conductivity.

\subsection{Macroscopic-3D Graphene}

Since the debut of graphene, building graphene-based 3D porous materials has received increasing attention [78-83]. The approaches to prepare 3D-G can be divided into three categories as shown in Figure 4: (i) self assembly; (ii) the template assisted assembly chemical method; and (iii) the CVD method.

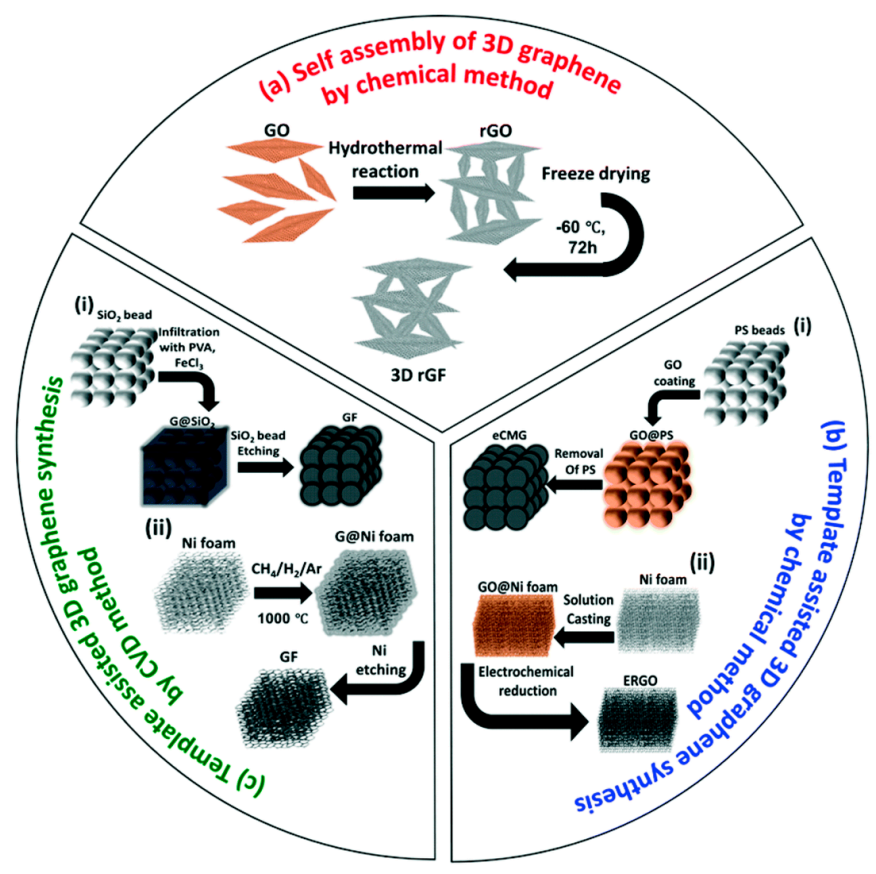

Figure 4. Schematic diagram for the fabrication strategy of 3D graphene. Note: GO represents graphene oxide, rGO represents reduced graphene oxide, GF represents graphene foams, rGF represents reduced graphene foams. Reproduced from [78] with permission from The Royal Society of Chemistry. Copyright 2015.

\subsubsection{Chemical Assembly Method}

Up to now, the most widely-used approaches to prepare 3D-G are the self-assembly of GO and their derivatives in solution and/or at interfaces. GO is an ideal building block for 3D macroscopic 
assembly due to the planar structure and the abundant processable groups, such as the hydroxyl, carboxyl and epoxy groups. Moreover, the mass production of GO can be achieved by the modification of Hummers' method from inexpensive graphite. Ample techniques, such as chemical reduction [84], electrochemical reduction [85], hydrothermal reduction [29], the dip coating method [30], the sol-gel method [31], the metal ion induced self-assembly process [86] and vacuum centrifugation [87], could be used to build 3D-G. Generally, the assembly of GO contains the following procedures. First, GO is uniformly dispersed in aqueous solution due to the electrostatic repulsion effect and hydrophilicity; then, GOs were treated with various reduction procedures to become more hydrophobic. The force to drive the construction of the 3D structure is supramolecular interactions (e.g., hydrogen bonding, van der Waals force, $\pi-\pi$ interactions). The $3 \mathrm{D}$ assembling process subsequently occurs. Meanwhile, heteroatom-doped 3D-G can be gained during this process. At last, a freeze drying process is used to get the macroscopic 3D-G structure.

In the work of $\mathrm{Xu}$, the self-assembled graphene hydrogel with thermally-stable, mechanically-strong and electrically-conductive characteristics was obtained by a one-step hydrothermal method [29]. The 3D structure was formed by partially coalescing or overlapping of the graphene. The combination of $\pi-\pi$ interactions and hydrophobicity lead to a 3D random stacking during the hydrothermal processes.

Furthermore, a great deal of template-assisted methods has been employed to build 3D-G with controlled pore size and interconnections between graphene sheets [88-90]. For instance, Li et al. prepared a 3D graphene on nickel composite via controlled deposition of rGO on a nickel foam template [89]. The Ni foam was refluxed in GO solution and then reduced by hydrogen. The continuous 3D porous nickel scaffold can offer a continuous surface for GO coating.

The chemical assembled method has several advantages, such as high efficiency, low cost, simplicity and easy scale up. Consequently, serval attempts have been made to developed 3D-G.

\subsubsection{Template-Assisted CVD Method}

The 3D-G prepared by the chemical assembly method would suffer from structural instability and poor electrical conductivity caused by the insufficient reduction of GO. The template-assisted CVD method can supply a fundamentally different bottom-up procedure to construct 3D-G. The typical process of this method is as follows: first, growing a graphene layer on the surface of a 3D metal catalyst at high temperature; then a post-treatment is used to remove the catalyst or support. Usually, nickel is used as the sacrificial template and catalyst [91-95]. In addition, anodic aluminum oxide (AAO) [96], $\mathrm{ZnO}$ [97], pyrolyzed photoresist films [98] and $\mathrm{SiO}_{2}$ [99] can be applied as the scaffold to build the 3D macroscopic structure.

In the group of Cheng, a template-directed CVD technique was developed to fabricate 3D-G structures using nickel foams as templates and methane as the carbon source [92]. This technique can be regarded as a general approach for building 3D-G with high quality and outstanding electrical conductivity. Choosing different nickel foams (with different numbers of pores per inch) can conveniently control the networks and pore structures of 3D-G. The number of graphene layers and specific surface area can also be tuned by the methane concentration.

Obviously, this template-assisted CVD method is versatile and scalable, which can be used to get 3D-G with excellent conductivity and a well-interconnected structure.

\section{Application in Oxygen Reduction Reaction}

Because of many excellent properties of graphene family materials, such as large surface area, excellent conductivity, strong adhesion to catalyst and chemical/electrochemical stability, they are considered as promising candidates for ORR [80,81]. Furthermore, with the incorporation of heteroatoms into the lattice plane of graphene, the local electronic properties of graphene family materials can be modulated, and more active sites can also be generated. Thus, the ORR performance can be greatly improved by effectively enhancing the surface reactivity and surface energy $[18,78]$. 
Interestingly, in the research about the application of graphene family materials for ORR, most of them use the heteroatom-doped graphene family materials due to their superior performance.

\subsection{Graphene Quantum Dots}

GQDs possess significant quantum confinement and edge effects. Chen et al. synthesized GQD-supported palladium (Pd) NPs after thermal reduction and a hydrothermal process [100]. The GQDs in composite materials can promote the charge transfer from GQDs to Pd metal and hence weaken the interactions between catalyst NPs and oxygenated intermediates, thus improving ORR activity. The Pd/GQD material shows apparent electro-catalytic activity toward ORR.

Moreover, doping heteroatoms in GQDs can offer more active sites and tune their electronic characteristics, thus improving the ORR performance. The pioneering work of N-GQDs/graphene composites via the electrochemical approach for use as metal-free electrocatalysts for the ORR was reported by Qu et al. [101]. As shown in Figure 5, the sizes of the as-prepared GQDs are about 2-5 nm (Figure $5 \mathrm{a}, \mathrm{b}$ ), and their heights are around $1-2.5 \mathrm{~nm}$ (Figure 5c), corresponding to 1-5 graphene layers. The theoretical structure of these oxygen-related groups rich (O-rich) N-GQDs was shown in Figure 5d. Both pyridine-like and pyrrolic $\mathrm{N}$ atoms can be found, and the oxygen-related groups are mainly located at the edges of graphene layers, thus forming a compact stacking structure between layers within GQDs by hydrogen bonding. The N-GQDs with $4.3 \% \mathrm{~N}$ content (atomic ratio) could emit blue luminescence under irradiation. As shown in Figure 5f, a well-defined reduction peak can be found at $-0.27 \mathrm{~V}$ (vs. $\mathrm{Ag} / \mathrm{AgCl}$ ) in $\mathrm{O}_{2}$-saturated $\mathrm{KOH}$ solution. Compared with the commercial $\mathrm{Pt} / \mathrm{C}$ catalyst (Figure 5g), N-GQDs show no electrocatalytic activity specific to methanol oxidation. Figure $5 \mathrm{~h}$ shows that the $n$ value (transferred electron number per $\mathrm{O}_{2}$ molecule) for $\mathrm{N}-\mathrm{GQDs} / \mathrm{G}$ was around 3.6-4.4, suggesting a $4 \mathrm{e}^{-}$reduction pathway for ORR. Furthermore, it exhibits excellent stability, showing no obvious performance decay after two days of continuous cycling test (Figure 5i). The N-doping effect plays a key role for the enhancement of the catalytic activity. While the $\mathrm{N}$ atoms with excessive valence are introduced into the lattice plane, the local density state can be changed, and more $\pi$-electrons are detected [102]. Accordingly, the surface energy and $n$-type carrier concentration are increased. Besides, a net positive charge density could be generated to counterbalance the electronic affinity of $\mathrm{N}$ atoms. Therefore, the N-GQDs could easily attract electrons to facilitate the ORR.

Later on, a solution-based bottom-up approach was reported to get N-GQDs [103]. Specifically, by using small substituted benzene derivatives as the starting material, through a series of oxidative dehydrogenation steps, GQDs containing 176, 128 and 130 carbon atoms were synthesized, respectively, as shown in Figure 6b. From the Cyclic Voltammetry (CV) in $\mathrm{O}_{2}$-saturated solution, an obvious reduction peak around $-0.3 \mathrm{~V}$ (vs. saturated calomel electrode (SCE)) occurs (Figure 6c). The linear sweep voltammetry (LSV) shows a size-dependent electrocatalytic activity phenomenon in N-GQDs. GQD 1 (Figure 6) with greater molecular weights exhibits improved catalytic activity. This is because larger QDs are more easily oxidized with higher highest occupied molecular orbital (HOMO) levels. Further, this work also demonstrated that the nitrogen doping is important to enhance the catalytic activity, but the increase is not proportional to the nitrogen content. This research introduced a deep level of understanding of the role of the nitrogen content on ORR.

Following these important studies, tremendous attempts have been conducted to investigate the electrocatalytic activity of GQDs [104-109]. Those studies show that the existence of GQDs can drastically facilitate the ORR performance through altering the electronic characteristics and offering more active sites. Moreover, the GQDs can be used to build nanocomposite materials due to their small dimension and easy tunability with heteroatom doping. 

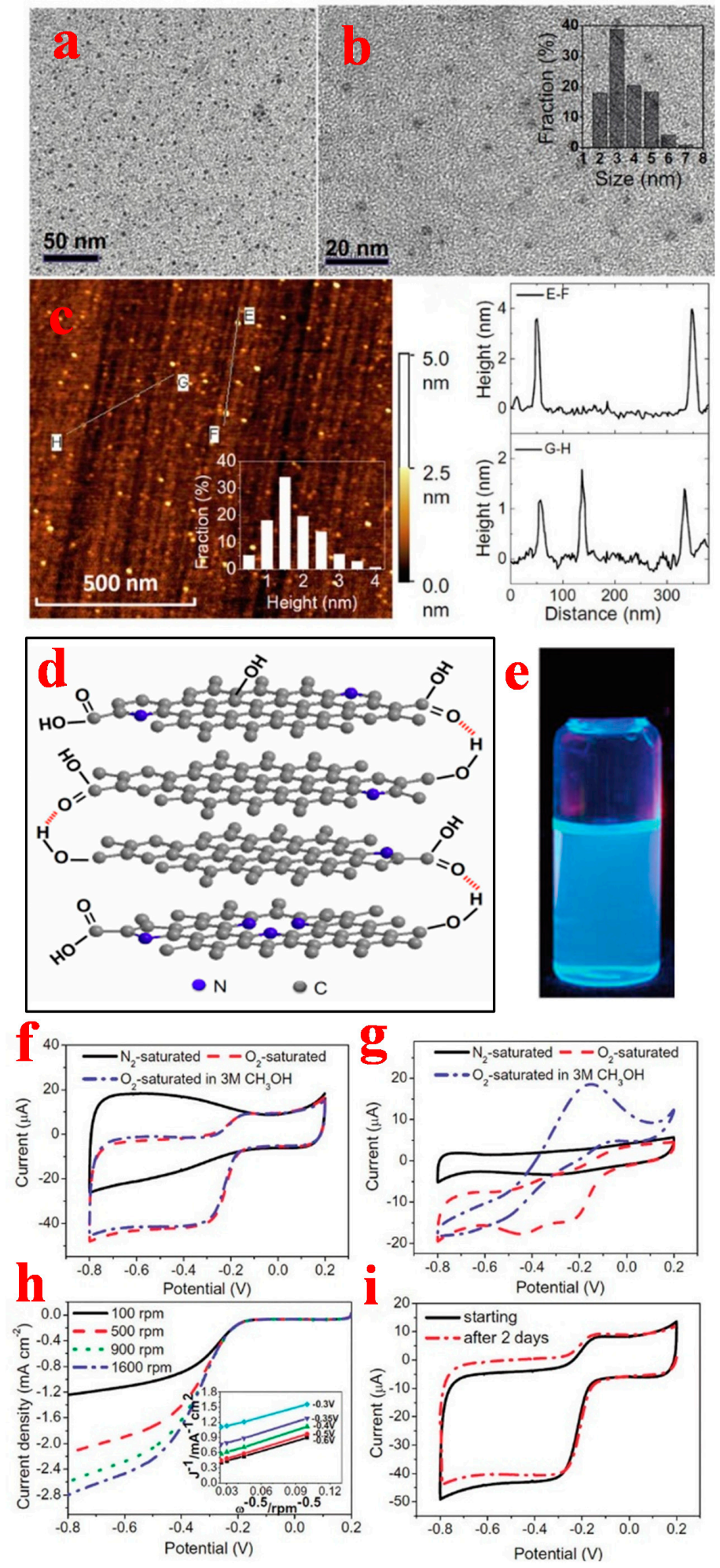

Figure 5. (a,b) TEM images and (c) AFM image of nitrogen-doped GQDs (N-GQDs) prepared by the electrochemical method; (d) schematic structure of O-rich N-GQDs; (e) photo of the as-prepared N-GQDs in water solution under irradiation; Cyclic Voltammetry (CV) curves of (f) N-GQDs / grapheme and (g) $\mathrm{Pt} / \mathrm{C}$ in $\mathrm{O}_{2}$ - and $\mathrm{N}_{2}$-saturated $0.1 \mathrm{M} \mathrm{KOH}$ and $3 \mathrm{M} \mathrm{CH} \mathrm{CH}_{3} \mathrm{OH}$ solution; (h) linear sweep voltammetry (LSV) curves for N-GQDs/graphene with different rotating speed; the inset shows the corresponding Koutecky-Levich (K-L) plots; (i) the stability test of N-GQD/graphene in $\mathrm{O}_{2}$-saturated $0.1 \mathrm{M} \mathrm{KOH}$. Reprinted with permission from [100]. Copyright 2012, American Chemical Society. 

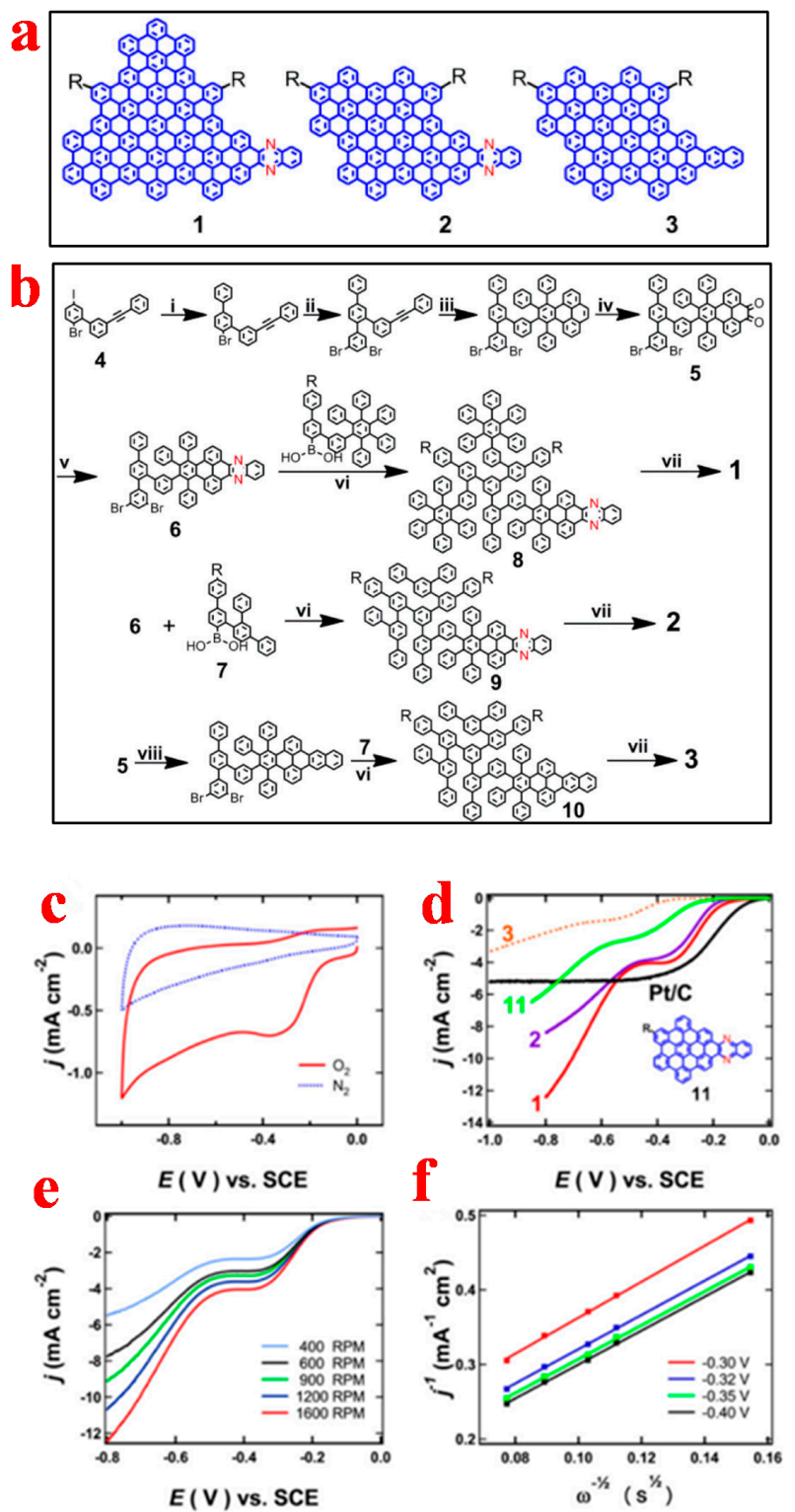

Figure 6. (a) Structures and (b) synthesis routes of three types of GQDs; (c) CV curves of GQD 1 in $\mathrm{O}_{2}$ - and $\mathrm{N}_{2}$-saturated $0.1 \mathrm{M} \mathrm{KOH}$ solution at a scan rate of $50 \mathrm{mV} \cdot \mathrm{s}^{-1}$ (vs. saturated calomel electrode (SCE) ); (d) LSV curves of these three GQDs and $\mathrm{Pt} / \mathrm{C}$ in $\mathrm{O}_{2}$-saturated $0.1 \mathrm{M} \mathrm{KOH}$ solution (1600 rpm); (e) LSV curves for GQD 1 with different rotating speeds; (f) K-L plots of GQD 1 from LSVs, giving an $n$ of $~ 3.9$. Reprinted with permission from [103]. Copyright 2012, American Chemical Society.

\subsection{Graphene Nanoribbons}

Due to their intrinsic properties, such as abundant edges, thin walls, high surface area and excellent electrical conductivity, GNRs are extremely attractive to enhance the ORR activity [110-118]. In Liu's group, they used longitudinal unzipping technology to produce GNRs from CNTs [110]. After reduction, in situ polymerization and the thermal treatment process, the N-GNRs were prepared as shown in Figure 7. The TEM image shows that the GNRs were bonded to each other after totally unzipping or opening the pristine CNTs. After polymerization, the PANI nanorods are uniformly dispersed on the GNR sheets without apparent aggregation. As shown in Figure 7d-g, compared with the GNRs, the N-GNRs show much higher current density, suggesting an enhanced ORR activity by the doping of the $\mathrm{N}$ element. The $n$ value for $\mathrm{N}_{8.3}$-GNRs is about 3.91 , exhibiting a dominant $4 \mathrm{e}^{-}$ORR process. For GNRs without nitrogen doping, the $n$ value is just 2.89 , indicating a combined $4 \mathrm{e}^{-}$and 
$2 \mathrm{e}^{-}$reduction pathway. The excellent ORR activity is related to the straight ribbon-like structure and the doped quaternary, pyridinic-N, which can activate the oxygen molecules. Conceptually, the $\mathrm{N}$ atom that was doped into a graphene basal plane and the $\mathrm{N}$ atoms that were placed in a six-member ring are defined as quaternary $\mathrm{N}$ and pyridinic $\mathrm{N}$, respectively. Most of the $\mathrm{N}$ atoms in N-GNRs are quaternary $\mathrm{N}$ and pyridinic $\mathrm{N}$ [110]. For quaternary $\mathrm{N}$, the electrons can transfer from the $\mathrm{C}$ atom to the adjacent $\mathrm{N}$ atom, then the $\mathrm{N}$ atom can donate back the electrons to the unoccupied $\mathrm{P}$ orbitals of the adjacent $\mathrm{C}$ atom. This process is beneficial to both the dissociation of the oxygen molecule on adjacent $\mathrm{C}$ atoms and the formation of the $\mathrm{C}-\mathrm{O}$ band. For the pyridinic $\mathrm{N}$, because of its edge position, the $\mathrm{O}_{2}$ can be directly bonded with the lone electron pair of $\mathrm{N}$ and, thus, be activated [119].

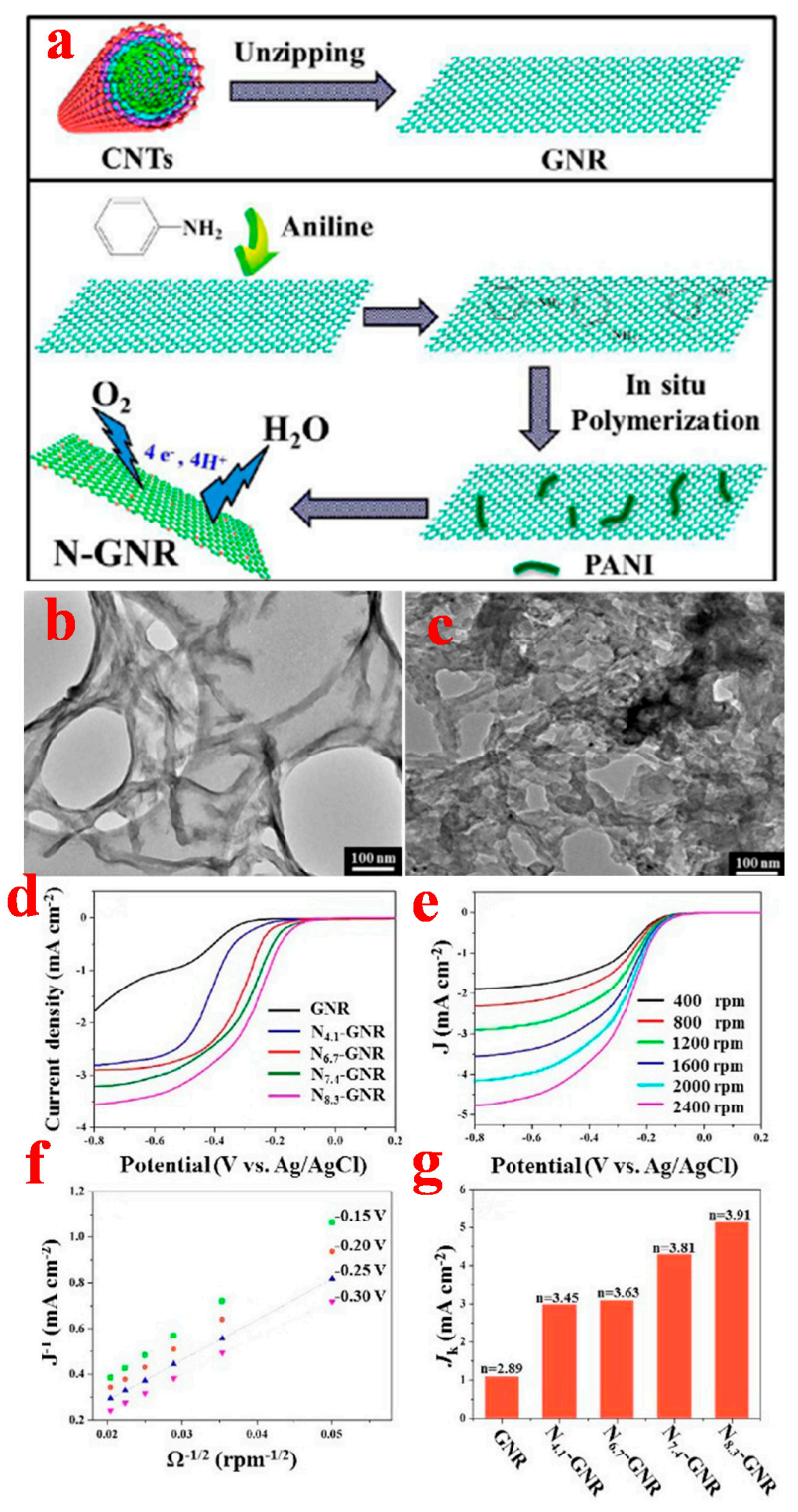

Figure 7. (a) Schematic charts for the synthesis of N-GNRs (nitrogen-doped graphene nanoribbons); TEM images of (b) pure GNRs sheets and (c) GNR/PANI composites; (d) LSV curves of GNRs and $\mathrm{N}$-GNRs in $\mathrm{O}_{2}$-saturated $0.1 \mathrm{M} \mathrm{KOH}$ solution (1600 rpm); (e) LSV curves for $\mathrm{N}_{8.3}$-GNRs with different rotating speeds; (f) K-L plots of GNRs and N-GNRs from LSVs; (g) kinetic-limiting current density at $0.7 \mathrm{~V}$ of GNRs and N-GNRs. Reprinted with permission from [110]. Copyright 2014, American Chemical Society. 
In addition, GNRs can be regarded as very promising catalyst support for ORR. Wang et al. used a one-step simultaneous reduction reaction to get the GQD/GNR composite [117]. As shown in Figure 8, the reduction of methylbenzene and hexabromobenzene by Na produced the GQD-GNR hybrid. The composite materials appear as a treelike fractal structure consisting of numerous nanoribbon branches supporting many dots. An obvious reduction peak at $-0.19 \mathrm{~V}$ (vs. Ag/ $\mathrm{AgCl}$ ) occurs in the $\mathrm{O}_{2}$-saturated $\mathrm{KOH}$ solution. The $n$ value for GQDs/GNRs is 3.91, exhibiting a dominant $4 \mathrm{e}^{-}$oxygen reduction process. The half-wave potential of GQDs/GNRs is more positive than that of commercial $\mathrm{Pt} / \mathrm{C}$. This can be attributed to the numerous active sites supplied by the abundant surface/edge defects and the interface in GQDs/GNRs, as well as the quick charge transfer between them.

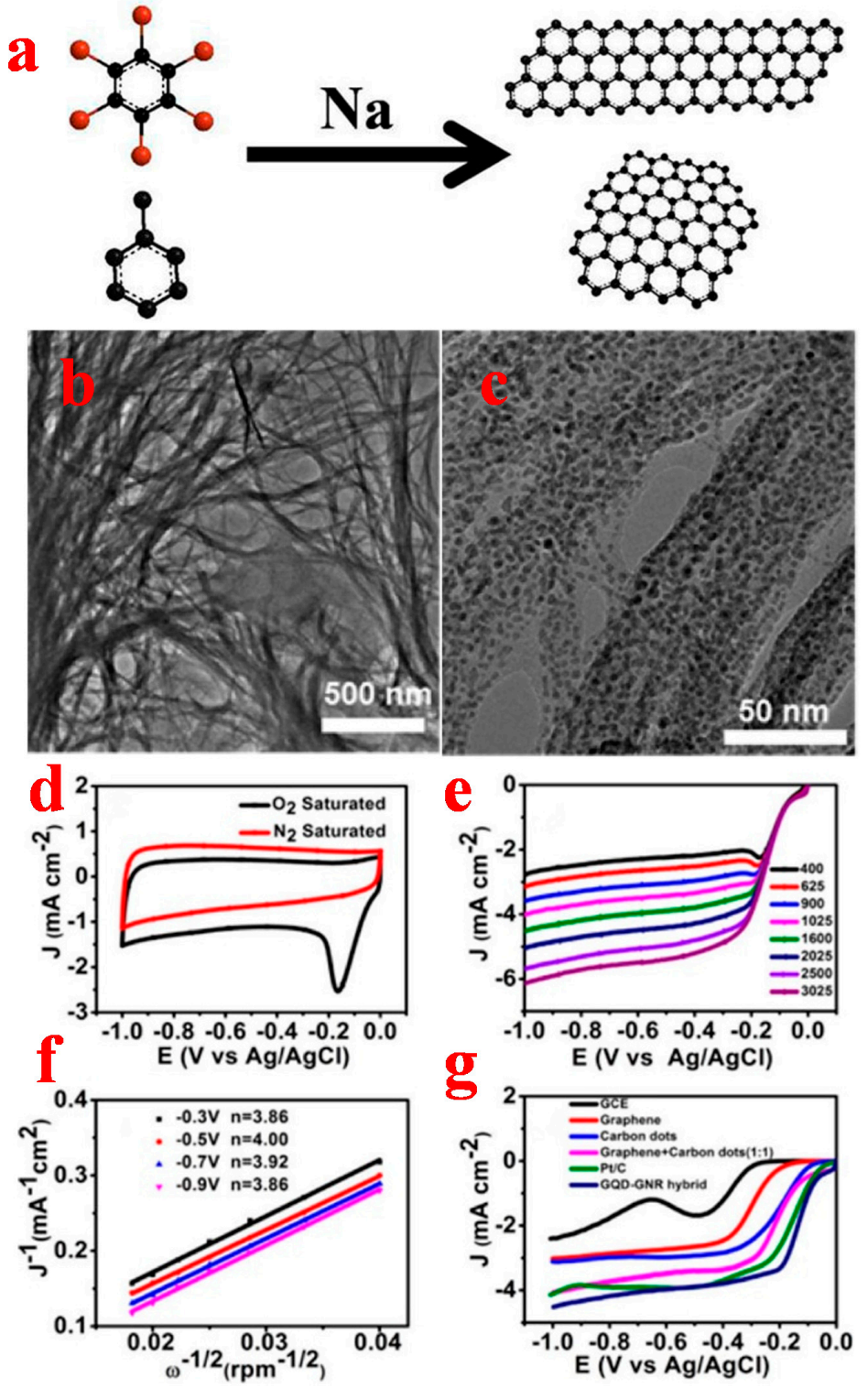

Figure 8. (a) Schematic charts for the synthesis of GQD-GNRs. (b,c) TEM images of GQD-GNR composites; (d) CV curves of GQD-GNR composites in $\mathrm{N}_{2}$ - and $\mathrm{O}_{2}$-saturated $0.1 \mathrm{M} \mathrm{KOH}$ solution; (e) LSV curves for GQD-GNR composites with different rotating speeds; (f) K-L plots of GQD-GNR composites from LSVs; (g) LSV curves of different electrocatalysts in $\mathrm{O}_{2}$-saturated $0.1 \mathrm{M} \mathrm{KOH}$ solution. Reprinted with permission from [117]. Copyright 2015, American Chemical Society.

The applications of GNRs can also be easily extended to other metal/metal oxides [112-115,118]. For example, combining GNRs with nanoparticles to form a hybrid is conceivable to integrate their 
respective merits and enhance their catalytic activity. A series of $\mathrm{Fe}_{3} \mathrm{C}-\mathrm{GNR}, \mathrm{Co}_{3} \mathrm{C}-\mathrm{GNRs}$ and $\mathrm{Ni}_{3} \mathrm{C}$-GNRs have been synthesized by the hot filament CVD method [115]. Such materials show excellent electrocatalytic activity for ORR with higher current density and better durability. In summary, the intrinsic properties of GNRs, such as the large surface area, excellent electrical conductivity, abundant edge sites and the inherent size, make them highly attractive for use as both metal-free catalysts and catalyst supports for heterogeneous catalysts.

\subsection{D Graphene}

With the interconnected macroporous framework and enhanced ion diffusion/electron transport paths in multidimensions, the 3D graphene structure is extremely desirable to improve the loading and dispersion of catalysts and supply more active sites for the reaction $[78,80,81,120-122]$. In the group of Pumera, a CVD method with nickel foam as the template was used to get 3D-G with different layer numbers [123]. All of the 3D-G can offer good catalytic properties towards ORR, and moreover, the ORR activity of 3D-G increased with the increasing number of graphene layers.

Furthermore, the 3D graphene can be doped with different heteroatoms, such as $\mathrm{N}, \mathrm{S}$ and $\mathrm{P}$, to enhance its catalytic activity. Qiao et al. prepared $\mathrm{N}$ and $\mathrm{S}$ dual-doped mesoporous graphene (3D-N, S-G) through a one-step doping process [124]. Since the 3D-N, S-G has more active sites, the ORR catalytic activity was significantly enhanced with higher reaction current and more positive onset potential. In Qu's group, a 3D-N, S-G with in-plane nano-pores (N-S-GMF) was reported [125]. As shown in Figure 9, the 3D-G/pyrrole (Py) was synthesized by traditional hydrothermal treatment. After thermal treatment, the $\mathrm{Fe}_{2} \mathrm{O}_{3}$ nanoparticle formed in situ on the graphene surface and etched the basal planes of graphene; thus, a holey graphene structure was obtained. A 3D graphene framework with high nanohole density and uniform pore size can be observed in the SEM and TEM images (Figure $9 \mathrm{~b}, \mathrm{c}$ ). An obvious reduction peak of N-S-GMF at $-0.1 \mathrm{~V}$ (vs. $\mathrm{Ag} / \mathrm{AgCl}$ ) occurs in the $\mathrm{O}_{2}$-saturated $\mathrm{KOH}$ solution. In the LSV test, N-S-GMF shows a high onset potential of about $0.04 \mathrm{~V}$, which is close to $\mathrm{Pt} / \mathrm{C}(20 \%)$ and more positive than that of the other catalysts. The $n$ value for N-S-GMF is approximately 3.6, exhibiting a dominant $4 \mathrm{e}^{-}$ORR process. The peroxide yield on the N-S-GMF was less than $15 \%$ in the rotating ring-disk electrode (RRDE) test. These remarkable ORR performances could be attributed to the rich porosity, unique pore-hierarchical structure, richly available active sites, multidimensional electron transport path and synergistic $\mathrm{N}$ and $\mathrm{S}$ co-doping effect. Besides, numerous research studies have been conducted on doped 3D-G as metal-free catalysts for ORR.

As shown above, with the porous structure and non-agglomerated morphology, the 3D-G is an excellent supporting material to allow the full utilization of the unique features. A great deal of carbon materials and metals or metal oxide nanoparticles have been used to build graphene-based 3D structures. For instance, Feng et al. fabricated a 3D N-doped graphene aerogel supporting $\mathrm{Fe}_{3} \mathrm{O}_{4}$ nanoparticles (3D $\mathrm{Fe}_{3} \mathrm{O}_{4} / \mathrm{N}$-Gas) by a one-pot hydrothermal method for the first time. $\mathrm{Fe}_{3} \mathrm{O}_{4}$ NPs uniformly deposit on the interconnected macroporous graphene structure, which is beneficial to enhance the interface contact and suppress the agglomeration and dissolution of NPs. The 3D- $\mathrm{Fe}_{3} \mathrm{O}_{4} / \mathrm{N}-\mathrm{G}$ exhibits a remarkable ORR activity associated with a more positive onset potential $(-0.19 \mathrm{~V}$ vs. $\mathrm{Ag} / \mathrm{AgCl})$, higher electron transfer number and lower $\mathrm{H}_{2} \mathrm{O}_{2}$ yield in alkaline media. In addition, 3D-G prepared by CVD was also used as the supporting material for the mesoporous $\mathrm{NiCO}_{2} \mathrm{O}_{4}$ nanoplate for ORR. The 3D-G foam was immersed in the precursor solution and then maintained at $160^{\circ} \mathrm{C}$ for $3 \mathrm{~h}$. As shown in Figure $10 \mathrm{a}, \mathrm{b}$, the as-formed $\mathrm{NiCo}_{2} \mathrm{O}_{4} \mathrm{NPs}$ grow vertically and uniformly cover the graphene surface to create a loose porous structure. An obvious reduction peak at $0.75 \mathrm{~V}$ (vs. reversible hydrogen electrode (RHE)) occurs in the $\mathrm{O}_{2}$-saturated $0.1 \mathrm{M} \mathrm{KOH}$ solution (Figure 10c). The $3 \mathrm{D}-\mathrm{NiCO}_{2} \mathrm{O}_{4} / \mathrm{G}$ material outperforms the commercial $\mathrm{Pt} / \mathrm{C}(20 \%)$ in terms of half-wave potential and limiting current. The $n$ value for GQDs/GNRs is 4.0, exhibiting a dominant $4 \mathrm{e}^{-}$oxygen reduction process. Due to the morphology and structure stability, the $3 \mathrm{D}-\mathrm{NiCo}_{2} \mathrm{O}_{4} / \mathrm{G}$ shows better stability than commercial $\mathrm{Pt} / \mathrm{C}$ (Figure 10d-f). 


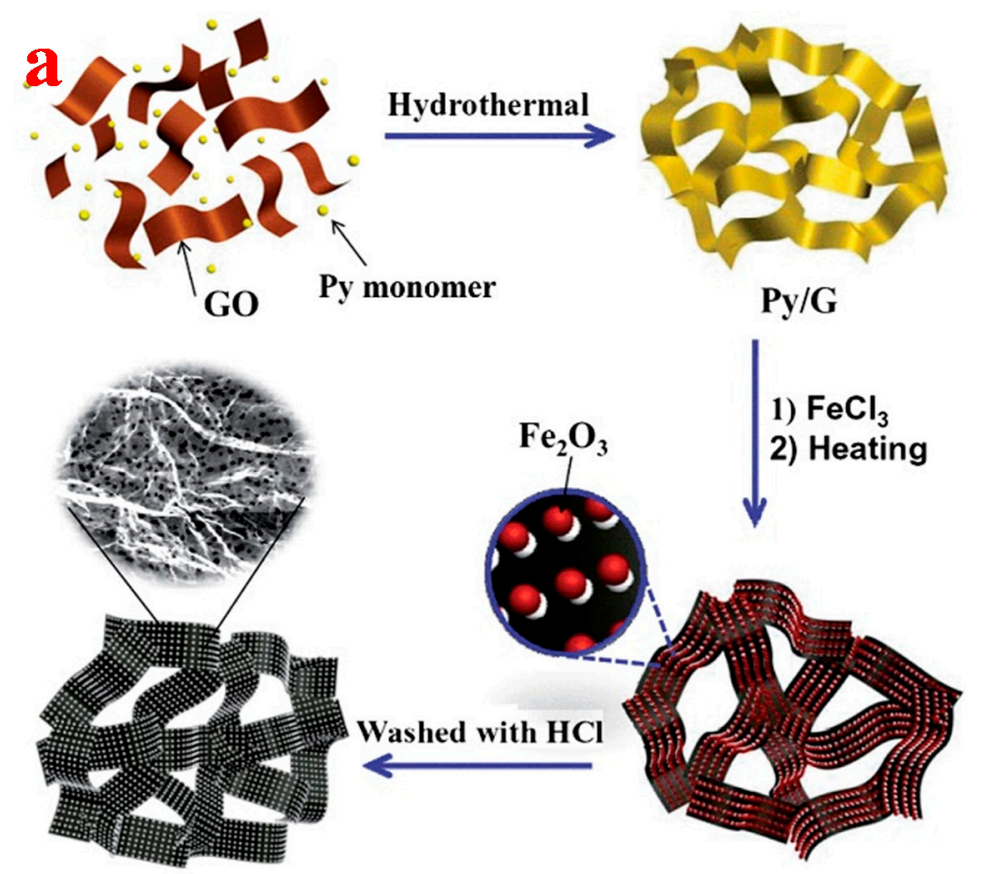

N-GMF
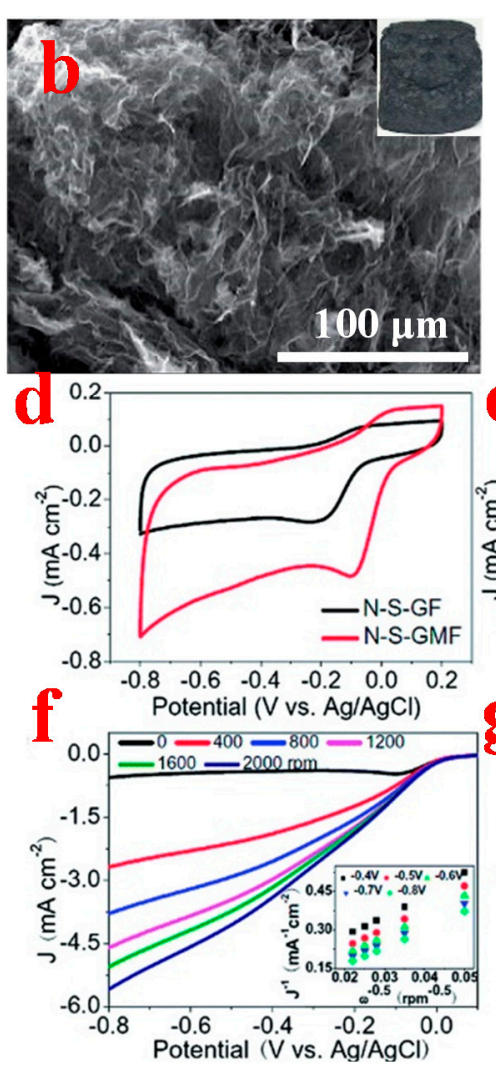

N-GMF with $\mathrm{Fe}_{2} \mathrm{O}_{3}$
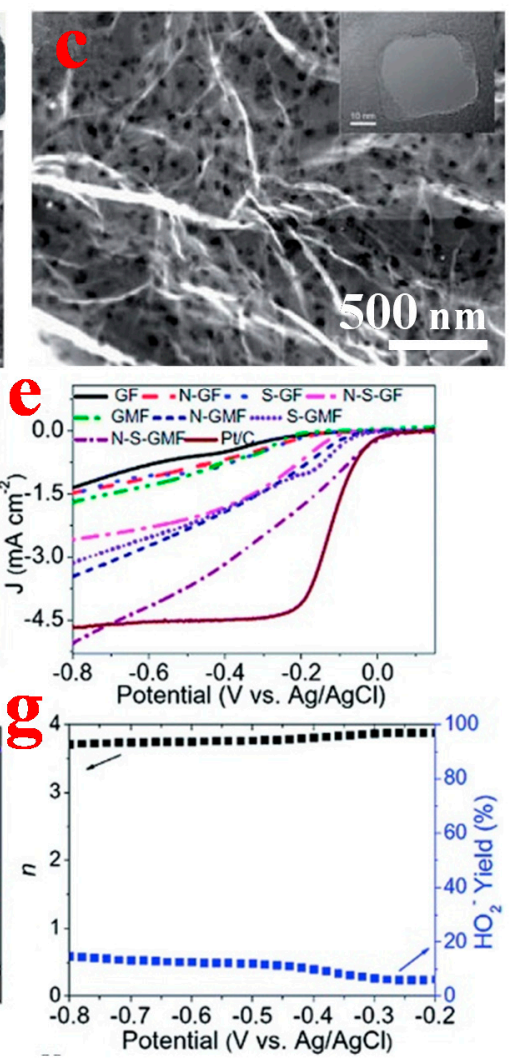

Figure 9. (a) Schematic charts for the synthesis of N-GMF (nitrogen-doped graphene nano-mesh foam); (b) SEM images of N-GMF; the inset is the photo of N-GMF; (c) scanning transmission electron microscopy (STEM) image of N-GMF; the inset is the TEM image of a single nano-hole with high magnification; (d) CV curves of N-S-GMF (N and S co-doped graphene nano-mesh foam) and N-S-GF ( $\mathrm{N}$ and $\mathrm{S}$ co-doped graphene foam) in $\mathrm{O}_{2}$-saturated $0.1 \mathrm{M} \mathrm{KOH}$ solution; (e) LSV curves of different electrocatalysts (1600 rpm); (f) rotating disk electrode (RDE) measurement of $\mathrm{N}-\mathrm{S}$-GMF in $\mathrm{O}_{2}$-saturated $0.1 \mathrm{M} \mathrm{KOH}$ with different rotating speeds; the inset shows the K-L plots from LSVs; (g) the $n$ and $\mathrm{HO}_{2}{ }^{-}$production of the N-S-GMF. Reproduced from [125] with permission from The Royal Society of Chemistry. Copyright 2014. 

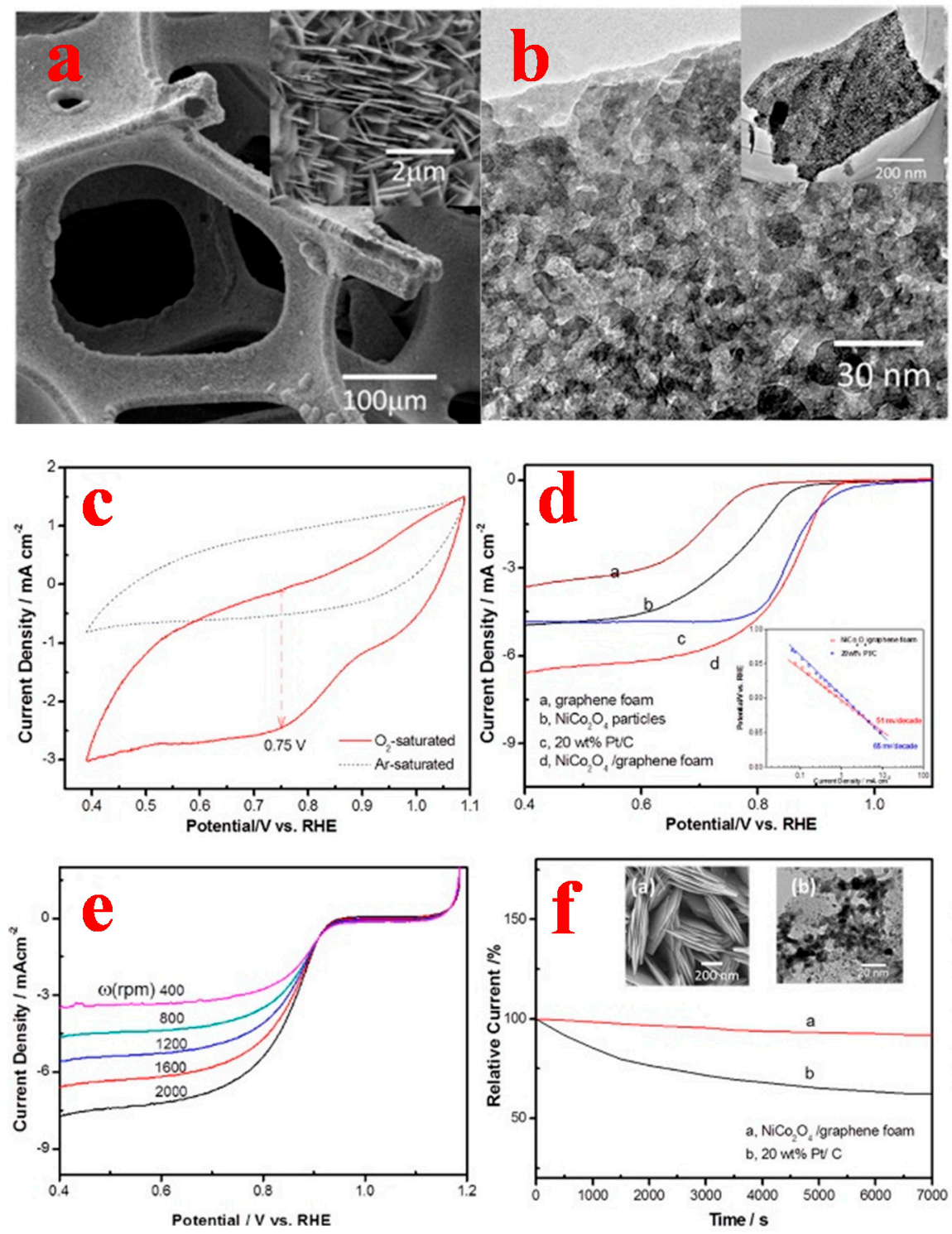

Figure 10. (a) SEM images of $\mathrm{NiCo}_{2} \mathrm{O}_{4} / 3 \mathrm{D}$-graphene; the inset shows that the as-prepared NPs grow vertically on the surface of 3D-G; (b) TEM image of $\mathrm{NiCo}_{2} \mathrm{O}_{4} / 3 \mathrm{D}-\mathrm{G}$; the inset is the TEM image with low magnification; (c) $\mathrm{CV}$ curves of $\mathrm{NiCO}_{2} \mathrm{O}_{4} / 3 \mathrm{D}-\mathrm{G}$ in $\mathrm{O}_{2}$ - and Ar- saturated $0.1 \mathrm{M} \mathrm{KOH}$ solution; (d) LSV curves of different electrocatalysts (1600 rpm); (e) LSV curves of $\mathrm{NiCo}_{2} \mathrm{O}_{4} / 3 \mathrm{D}-\mathrm{G}$ at different rotation rates at a scan rate of $10 \mathrm{mV} \cdot \mathrm{s}^{-1}$; (f) the stability test for $\mathrm{NiCo}_{2} \mathrm{O}_{4} / 3 \mathrm{D}-\mathrm{G}$ and $\mathrm{Pt} / \mathrm{C}(20 \%)$, measured by the current at $0.75 \mathrm{~V}$ vs. RHE; the insets are the SEM image of the (a) $\mathrm{NiCo}_{2} \mathrm{O}_{4} / 3 \mathrm{D}-\mathrm{G}$ and (b) $\mathrm{Pt} / \mathrm{C}$ after the test. Reprinted with permission from [126]. Copyright 2016, American Chemical Society.

In summary, with a large porous channel size, huge surface area and high electrical conductivity, the role of the 3D-G inspires more exciting developments. Table 1 lists a part of the recent reports and the summary of some typical work of 3D-G-based material on ORR. 
Table 1. Summary of some typical work of 3D-G-based material on ORR.

\begin{tabular}{|c|c|c|c|c|c|}
\hline The Catalyst & The Types of the Catalysts & Electro-Catalytic Performance & Onset Potential & $\begin{array}{c}\text { Electron Transfer } \\
\text { Number }\end{array}$ & Ref. \\
\hline 3D-Se-CNTs $/ \mathrm{G}^{1}$ & Metal NPs, supported & Excellent catalytic activity, long-term stability and a high methanol tolerance & - & 3.95 & [127] \\
\hline 3D-S,N-G & Mixed doped & $\begin{array}{c}\text { Excellent catalytic activity, including highly positive } \\
\text { onset potential and high kinetic limiting current }\end{array}$ & $-0.06 \mathrm{~V}$ vs. $\mathrm{Ag} / \mathrm{AgCl}$ & $3.3-3.6$ & [124] \\
\hline $\mathrm{Fe}_{3} \mathrm{O}_{4} / 3 \mathrm{D}-\mathrm{N}-\mathrm{G}^{2}$ & Metal oxide, supported & More positive onset potential, higher cathodic density, lower $\mathrm{H}_{2} \mathrm{O}_{2}$ yield & $-0.19 \mathrm{~V}$ vs. $\mathrm{Ag} / \mathrm{AgCl}$ & $3.72-3.95$ & [128] \\
\hline 3D-N-G & N-doped & Lower onset potential than that of $\mathrm{Pt} / \mathrm{C}$, higher diffusion current density & $0.18 \mathrm{~V}$ vs. $\mathrm{Ag} / \mathrm{AgCl}$ & 3.7 & [129] \\
\hline Co-3D-N-G & Metal oxide, supported & Excellent electrocatalytic activity for the ORR in alkaline electrolyte & $-0.05 \mathrm{~V}$ vs. $\mathrm{Ag} / \mathrm{AgCl}$ & 3.97 & [130] \\
\hline $\begin{array}{l}\text { N-macro-mesoporous } \\
\text { carbon/3D-G }\end{array}$ & Nanomaterial, supported & $\begin{array}{l}\text { Excellent ORR activity, a complete tolerance to methanol } \\
\text { cross-over effect and excellent long-term durability }\end{array}$ & $-0.05 \mathrm{~V}$ vs. $\mathrm{Ag} / \mathrm{AgCl}$ & - & [131] \\
\hline 3D-N-G & N-doped & $\begin{array}{l}\text { One of the best performing NGs for ORR electrocatalysis } \\
\text { and superior to other scalable preparation methods }\end{array}$ & $-0.2 \mathrm{~V}$ vs. $\mathrm{Ag} / \mathrm{AgCl}$ & $3.8-3.9$ & [132] \\
\hline $3 \mathrm{D}-\mathrm{N}-\mathrm{G}$ & N-doped & $\begin{array}{l}\text { Large kinetic-limiting current density, long-term stability } \\
\text { and good tolerance to methanol crossover }\end{array}$ & $-0.2 \mathrm{~V}$ vs. $\mathrm{Ag} / \mathrm{AgCl}$ & $3.8-3.9$ & [133] \\
\hline $3 \mathrm{D}-\mathrm{B}, \mathrm{N}-\mathrm{G}$ & Mixed doped & $\begin{array}{l}\text { A higher current generation capability, better stability } \\
\text { and superior tolerance to the methanol crossover effect }\end{array}$ & -0.16 V vs. SCE & $3.4-3.8$ & [134] \\
\hline $\mathrm{Mn}_{3} \mathrm{O}_{4} / 3 \mathrm{D}-\mathrm{N}-\mathrm{G}$ & Metal oxide supported & Improved durability and methanol tolerance, far exceeding the commercial Pt/C & $-0.1 \mathrm{~V}$ vs. $\mathrm{Ag} / \mathrm{AgCl}$ & 3.7 & [135] \\
\hline 3D-S-G & S-doped & $\begin{array}{c}\text { A much enhanced ORR catalytic activity, } \\
\text { as well as an especially high electrochemical stability }\end{array}$ & - & - & [136] \\
\hline $3 \mathrm{D}-\mathrm{N}-\mathrm{G}$ & N-doped & $\begin{array}{l}\text { A truly metal-free electrocatalyst material for } \\
\text { the oxygen reduction reaction in acid medium }\end{array}$ & $0.83 \mathrm{~V}$ vs. RHE & $2.6-3.5$ & [137] \\
\hline Pt/3D-G & Metal NPs, supported & $\begin{array}{l}\text { Much better durability, out-performing the } \\
\text { undoped sample after } 6000 \text { start-stop cycles }\end{array}$ & $1.05 \mathrm{~V}$ vs. RHE & - & [138] \\
\hline $\mathrm{C}_{3} \mathrm{~N}_{4}-3 \mathrm{D}-\mathrm{G}$ & NPs, supported & $\begin{array}{l}\text { Significantly enhanced electrocatalytic activity in terms of the } \\
\text { electron-transfer number, current density and onset potential }\end{array}$ & $-0.3 \mathrm{~V}$ vs. $\mathrm{Ag} / \mathrm{AgCl}$ & 3.7 & [139] \\
\hline 3D-G & pristine & Multilayer 3D graphene exhibits higher electrocatalytic activity & $-0.252 \mathrm{~V}$ vs. $\mathrm{Ag} / \mathrm{AgCl}$ & - & [123] \\
\hline $\mathrm{Fe}_{x} \mathrm{~N} / 3 \mathrm{D}-\mathrm{G}$ & NPs, supported & $\begin{array}{l}\text { Comparable catalytic activity as commercial } \mathrm{Pt} / \mathrm{C} \text {, while its stability } \\
\text { and resistance to methanol crossover are superior }\end{array}$ & $0.00 \mathrm{~V}$ vs. $\mathrm{Ag} / \mathrm{AgCl}$ & 4.0 & [140] \\
\hline $\mathrm{TiO}_{2} / 3 \mathrm{D}-\mathrm{N}-\mathrm{G}$ & Metal oxide supported & $\begin{array}{l}\text { Great ORR electrocatalytic performance and long durability } \\
\text { and methanol tolerance than that of } 20 \% \mathrm{Pt} / \mathrm{C}\end{array}$ & $0.005 \mathrm{~V}$ vs. $\mathrm{Hg} / \mathrm{HgO}$ & 3.85 & [141] \\
\hline $\begin{array}{l}\text { N-S-3D-graphene } \\
\text { nano-mesh }\end{array}$ & Mixed doped & $\begin{array}{l}\text { Excellent electrocatalytic activity for ORR, better than most } \\
\text { of the graphene-based catalysts reported }\end{array}$ & $0.04 \mathrm{~V}$ vs. $\mathrm{Ag} / \mathrm{AgCl}$ & 3.6 & [125] \\
\hline $\mathrm{MnO} / 3 \mathrm{D}-\mathrm{G}$ & Metal oxide, supported & $\begin{array}{l}\text { Enhanced catalytic current, more positive potential, } \\
\text { excellent methanol tolerance and long-term stability }\end{array}$ & $-0.22 \mathrm{~V}$ vs. $\mathrm{Ag} / \mathrm{AgCl}$ & 3.03 & [142] \\
\hline $\mathrm{Pt} / \mathrm{N}-3 \mathrm{D}-\mathrm{G}$ & Metal NPs, supported & $\begin{array}{l}\text { Improvement in the support can reach } 2.6 \text {-times the catalytic activity } \\
\text { and almost no degradation after } 5000 \text { cycles }\end{array}$ & $1.05 \mathrm{~V}$ vs. RHE & - & [143] \\
\hline Pt/3D-G & Metal NPs, supported & Enhanced electrocatalytic activity and improved durability & $0.95 \mathrm{~V}$ vs. RHE & - & [144] \\
\hline
\end{tabular}


Table 1. Cont.

\begin{tabular}{|c|c|c|c|c|c|}
\hline The Catalyst & The Types of the Catalysts & Electro-Catalytic Performance & Onset Potential & $\begin{array}{l}\text { Electron Transfer } \\
\text { Number }\end{array}$ & Ref. \\
\hline 3D-N-G & N-doped & Comparable electrocatalytic performance with the commercial $\mathrm{Pt} / \mathrm{C}$ in alkaline & $-0.05 \mathrm{~V}$ vs. $\mathrm{Ag} / \mathrm{AgCl}$ & 3.79 & [145] \\
\hline N-B-3D-G & Dual doped & $\begin{array}{l}\text { The onset potential and current density of } \mathrm{N} \text { and } \mathrm{B} \text { co-doped 3D-G are } \\
\text { comparable to those of the commercial } \mathrm{Pt}(30 \%) / \mathrm{C} \text { catalyst }\end{array}$ & $-0.04 \mathrm{~V}$ vs. $\mathrm{Ag} / \mathrm{AgCl}$ & 3.8 & [146] \\
\hline 3D-N-B-G & Dual doped & $\begin{array}{l}\text { The onset potential, half-wave potential and limiting current density } \\
\text { were comparable to or even better than those in previous reports }\end{array}$ & $-0.07 \mathrm{~V}$ vs. SCE & 3.9 & [147] \\
\hline N-3D-G & N-doped & $\begin{array}{l}\text { A high diffusion-limited current, superior durability and } \\
\text { better immunity towards methanol crossover in alkaline solution }\end{array}$ & $0.9 \mathrm{~V}$ vs. RHE & $4.2-4.6$ & [148] \\
\hline $\mathrm{Pd} / 3 \mathrm{D}-\mathrm{G}$ & Metal NPs, supported & $\begin{array}{l}\text { Enhancement in the reduction current, lower stability than } \mathrm{Pt} / \mathrm{C} \text {, } \\
\text { but free from the catalytic poisoning }\end{array}$ & $-0.65 \mathrm{~V}$ vs. NHE & - & [149] \\
\hline 3D-N-G & N-doped & $\begin{array}{c}\text { Remarkable ORR activity and long-term stability } \\
\text { in both alkaline and acidic solutions }\end{array}$ & $0.83 \mathrm{~V}$ vs. RHE & 3.9 & [150] \\
\hline B-3D-G & B-doped & $\begin{array}{l}\text { Comparable to Pt/C (20 wt \%) catalyst, in addition to their superior } \\
\text { durability and resistance to the crossover effect }\end{array}$ & $-0.05 \mathrm{~V}$ vs. $\mathrm{Ag} / \mathrm{AgCl}$ & 4.16 & [151] \\
\hline Co-N-3D-G & Metal NPs, supported & $\begin{array}{l}\text { Significant catalytic activity with positive onset and } \\
\text { half-wave potentials, low hydrogen peroxide yield, } \\
\text { high resistance to methanol crossover and remarkable stability }\end{array}$ & $0.99 \mathrm{~V}$ vs. RHE & $3.94-3.97$ & [152] \\
\hline $\mathrm{CoMn}_{2} \mathrm{O}_{4} / \mathrm{N}-\mathrm{P}-3 \mathrm{D}-\mathrm{G}$ & $\begin{array}{l}\text { Metal oxide, dual doped, } \\
\text { supported }\end{array}$ & More positive onset potential and amazingly high current density towards the ORR & $-0.094 \mathrm{~V}$ vs. SCE & $3.64-3.70$ & [153] \\
\hline $\mathrm{Co}_{3} \mathrm{O}_{4} / \mathrm{N}-\mathrm{S}-3 \mathrm{D}-\mathrm{G}$ & $\begin{array}{l}\text { Metal oxide, dual doped, } \\
\text { supported }\end{array}$ & $\begin{array}{l}\text { Favored a } 4 \mathrm{e}^{-} \text {pathway in catalyzing ORR } \\
\text { and exhibited intrinsic long-term durability }\end{array}$ & -0.05 V vs. SCE & 3.7 & [154] \\
\hline $\mathrm{NiCo}_{2} \mathrm{O}_{4} / 3 \mathrm{D}-\mathrm{G}$ & Metal oxide, supported & $\begin{array}{l}\text { Outstanding ORR performance with the four-electron } \\
\text { reduction of } \mathrm{O}_{2} \text { to } \mathrm{H}_{2} \mathrm{O} \text { in alkaline media }\end{array}$ & $0.95 \mathrm{~V}$ vs. RHE & 4.0 & [126] \\
\hline GQDs/3D-G & Nanomaterial, supported & Enhanced electrocatalytic activity, good durability in alkaline solution & $-0.13 \mathrm{~V}$ vs. $\mathrm{Ag} / \mathrm{AgCl}$ & $3.2-4.0$ & [109] \\
\hline $\mathrm{Co} / \mathrm{CoO} / 3 \mathrm{D}-\mathrm{G}$ & Metal oxide, supported & $\begin{array}{l}\text { Comparable oxygen reduction performance with excellent } \\
\text { methanol resistance and better durability }\end{array}$ & $-0.06 \mathrm{~V}$ vs. $\mathrm{Ag} / \mathrm{AgCl}$ & 3.5 & [155] \\
\hline N-S-3D-G & Dual doped & $\begin{array}{l}\text { Higher electrocatalytic activity and diffusion-limiting } \\
\text { current density, better stability and methanol tolerance }\end{array}$ & $-0.12 \mathrm{~V}$ vs. SCE & 3.5 & [156] \\
\hline $\mathrm{CoFe}_{2} \mathrm{O}_{4} / 3 \mathrm{D}-\mathrm{N}-\mathrm{S}-\mathrm{G}$ & $\begin{array}{l}\text { Metal oxide, dual doped, } \\
\text { supported }\end{array}$ & A pronounced ORR activity (4-electron pathway) and high durability & -0.10 V 3D-N-G & $3.85-3.95$ & [157] \\
\hline Co/3D-G & Metal NPs, supported & Extraordinarily superior activity along with better stability & $0.9 \mathrm{~V}$ vs. RHE & 3.5 & [158] \\
\hline
\end{tabular}

${ }^{1} \mathrm{X}$ means X element doped. For instance, Se-G means selenium-doped grapheme; ${ }^{2} \mathrm{X} / \mathrm{Y}$ means Y-supported X. For instance, $\mathrm{Fe}_{3} \mathrm{O}_{4} / 3 \mathrm{D}-\mathrm{N}-\mathrm{G}$ means N-doped graphene-supported

$\mathrm{Fe}_{3} \mathrm{O}_{4}$ three-dimensional structure. 


\section{Conclusions and Future Outlook}

Due to the flexible structures and tunable functionalities, graphene can be considered as a versatile building block for other types of graphene-based materials, named the new graphene family materials, including GQDs, GNRs and 3D-G. These new structures show remarkable and unique properties, meanwhile keeping the excellent intrinsic properties of pristine graphene, such as a high surface area, high conductivity and high mechanical strengths.

For GQDs, because of the special structures with the atomic size, they should be supported on the substrate for ORR applications. With the introductions of GQDs on the substrate, the electrical neutrality of the substrate can be broken, and some new active sites for oxygen desorption and adsorption are generated; thus, ORR performance can be notably improved. Besides, the abundant edges of GQDs can also supply more catalytic active sites for ORR.

For GNRs, the excellent mechanical, physical and electrical properties make them extremely attractive for using as catalyst supports. Furthermore, due to the exposed edges along with the inherent size and high length-to-width ratio of GNRs, the ORR activity is promoted because of the significant reduction in the barriers posed to the first electron transfer and the oxygen adsorption on active edges.

For 3D-G, the 3D open structure could suppress the stacking and aggregation of graphene layers and therefore provide a good conducting network. Moreover, the 3D-G could not only supply abundant active sites, but also endow the material the features of fast ion diffusion and electron transfer in the catalytic process. To the best of our knowledge, research about 3D-G for ORR applications is the most promising field because of it easy preparation and high economic efficiency, as seen in a large number of the latest excellent articles.

Although there are various forms in the new graphene family materials, they share some characteristics in common. The large specific area, high accessibility and superior electrical conductivity render these materials ideal candidates for the application in ORR. In addition, these new graphene family materials can easily be doped with heteroatoms, intrinsically alter the electronic characteristics and facilitate ORR performance.

The findings of these new graphene family materials enriched our understanding greatly about graphene and open up new opportunities for their potential applications. Predictably, the different structures of these new graphene family materials will allow them to be suitable for various applications. However, this is just the beginning, and the expansion of graphene family materials fabrication and their applications in ORR are surely coming. There is tremendous room for the continuous development of the new graphene family materials. Importantly, the wide-spread commercial applications of the new graphene family materials highly rely on the advanced fabrication technology for the large-scale synthesis with low cost, which involves effective separation and dispersion of the products. Moreover, a deep understanding of the role and mechanism of the new graphene family materials in ORR will be an important guide to design and construct more desired structures.

Acknowledgments: We thank the support from the United Foundation of Guizhou Science and Technology Department-Guizhou Normal University (LKS No. [2013]11 and LKS No. [2014]9), Fonds de Recherche du Québec-Natureet Technologies (FRQNT), the Natural Sciences and Engineering Research Council of Canada (NSERC), Institut National de la Recherche Scientifique (INRS), Centre Québécois sur les Materiaux Fonctionnels (CQMF) and the China Scholarship Council (CSC).

Conflicts of Interest: The authors declare no conflict of interest.

\section{References}

1. Yang, Z.; Nie, H.; Chen, X.A.; Chen, X.; Huang, S. Recent progress in doped carbon nanomaterials as effective cathode catalysts for fuel cell oxygen reduction reaction. J. Power Sources 2013, 236, 238-249. [CrossRef]

2. Wu, G.; Zelenay, P. Nanostructured nonprecious metal catalysts for oxygen reduction reaction. Acc. Chem. Res. 2013, 46, 1878-1889. [CrossRef] [PubMed] 
3. Yang, Z.; Ren, J.; Zhang, Z.; Chen, X.; Guan, G.; Qiu, L.; Zhang, Y.; Peng, H. Recent advancement of nanostructured carbon for energy applications. Chem. Rev. 2015, 115, 5159-5223. [CrossRef] [PubMed]

4. Geng, D.; Ding, N.; Andy Hor, T.S.; Liu, Z.; Sun, X.; Zong, Y. Potential of metal-free "graphene alloy" as electrocatalysts for oxygen reduction reaction. J. Mater. Chem. A 2015, 3, 1795-1810. [CrossRef]

5. Wei, Q.; Tong, X.; Zhang, G.; Qiao, J.; Gong, Q.; Sun, S. Nitrogen-doped carbon nanotube and graphene materials for oxygen reduction reactions. Catalysts 2015, 5, 1574-1602. [CrossRef]

6. Guo, S.; Zhang, S.; Sun, S. Tuning nanoparticle catalysis for the oxygen reduction reaction. Angew. Chem. Int. Ed. 2013, 52, 8526-8544. [CrossRef] [PubMed]

7. Nie, Y.; Li, L.; Wei, Z. Recent advancements in Pt and Pt-free catalysts for oxygen reduction reaction. Chem. Soc. Rev. 2015, 44, 2168-2201. [CrossRef] [PubMed]

8. Wang, D.-W.; Su, D. Heterogeneous nanocarbon materials for oxygen reduction reaction. Energy Environ. Sci. 2014, 7, 576-591. [CrossRef]

9. Dai, L.; Xue, Y.; Qu, L.; Choi, H.-J.; Baek, J.-B. Metal-free catalysts for oxygen reduction reaction. Chem. Rev. 2015, 115, 4823-4892. [CrossRef] [PubMed]

10. Song, Z.; Cheng, N.; Lushington, A.; Sun, X. Recent progress on MOF-derived nanomaterials as advanced electrocatalysts in fuel cells. Catalysts 2016, 6, 116. [CrossRef]

11. Choi, H.-J.; Jung, S.-M.; Seo, J.-M.; Chang, D.W.; Dai, L.; Baek, J.-B. Graphene for energy conversion and storage in fuel cells and supercapacitors. Nano Energy 2012, 1, 534-551. [CrossRef]

12. Zhang, J.; Zhao, F.; Zhang, Z.; Chen, N.; Qu, L. Dimension-tailored functional graphene structures for energy conversion and storage. Nanoscale 2013, 5, 3112-3126. [CrossRef] [PubMed]

13. Chabot, V.; Higgins, D.; Yu, A.P.; Xiao, X.C.; Chen, Z.W.; Zhang, J.J. A review of graphene and graphene oxide sponge: Material synthesis and applications to energy and the environment. Energy Environ. Sci. 2014, 7, 1564-1596. [CrossRef]

14. Holade, Y.; Sahin, N.; Servat, K.; Napporn, T.; Kokoh, K. Recent advances in carbon supported metal nanoparticles preparation for oxygen reduction reaction in low temperature fuel cells. Catalysts 2015, 5, 310-348. [CrossRef]

15. Ni, J.; Li, Y. Carbon nanomaterials in different dimensions for electrochemical energy storage. Adv. Energy Mater. 2016. [CrossRef]

16. Liu, J.; Tang, J.; Gooding, J.J. Strategies for chemical modification of graphene and applications of chemically modified graphene. J. Mater. Chem. 2012, 22, 12435-12452. [CrossRef]

17. Usachov, D.; Vilkov, O.; Grüneis, A.; Haberer, D.; Fedorov, A.; Adamchuk, V.K.; Preobrajenski, A.B.; Dudin, P.; Barinov, A.; Oehzelt, M.; et al. Nitrogen-doped graphene: Efficient growth, structure, and electronic properties. Nano Lett. 2011, 11, 5401-5407. [CrossRef] [PubMed]

18. Jun, G.H.; Jin, S.H.; Lee, B.; Kim, B.H.; Chae, W.-S.; Hong, S.H.; Jeon, S. Enhanced conduction and charge-selectivity by $\mathrm{N}$-doped graphene flakes in the active layer of bulk-heterojunction organic solar cells. Energy Environ. Sci. 2013, 6, 3000-3006. [CrossRef]

19. Geim, A.K.; Novoselov, K.S. The rise of graphene. Nat. Mater. 2007, 6, 183-191. [CrossRef] [PubMed]

20. Cong, H.-P.; Chen, J.-F.; Yu, S.-H. Graphene-based macroscopic assemblies and architectures: An emerging material system. Chem. Soc. Rev. 2014, 43, 7295-7325. [CrossRef] [PubMed]

21. Di Bartolomeo, A. Graphene Schottky diodes: An experimental review of the rectifying graphene/semiconductor heterojunction. Phys. Rep. 2016, 606, 1-58. [CrossRef]

22. Li, X.; Rui, M.; Song, J.; Shen, Z.; Zeng, H. Carbon and graphene quantum dots for optoelectronic and energy devices: A review. Adv. Funct. Mater. 2015, 25, 4929-4947. [CrossRef]

23. Zheng, X.T.; Ananthanarayanan, A.; Luo, K.Q.; Chen, P. Glowing graphene quantum dots and carbon dots: Properties, syntheses, and biological applications. Small 2015, 11, 1620-1636. [CrossRef] [PubMed]

24. Zhu, S.; Song, Y.; Zhao, X.; Shao, J.; Zhang, J.; Yang, B. The photoluminescence mechanism in carbon dots (graphene quantum dots, carbon nanodots, and polymer dots): Current state and future perspective. Nano Res. 2015, 8, 355-381. [CrossRef]

25. Chen, L.; Hernandez, Y.; Feng, X.; Müllen, K. From nanographene and graphene nanoribbons to graphene sheets: Chemical synthesis. Angew. Chem. Int. Ed. 2012, 51, 7640-7654. [CrossRef] [PubMed]

26. Yazyev, O.V. A guide to the design of electronic properties of graphene nanoribbons. Acc. Chem. Res. 2013, 46, 2319-2328. [CrossRef] [PubMed] 
27. Ma, L.; Wang, J.; Ding, F. Recent progress and challenges in graphene nanoribbon synthesis. Chemphyschem 2013, 14, 47-54. [CrossRef] [PubMed]

28. Wei, W.; Yang, S.; Zhou, H.; Lieberwirth, I.; Feng, X.; Müllen, K. 3D graphene foams cross-linked with pre-encapsulated $\mathrm{Fe}_{3} \mathrm{O}_{4}$ nanospheres for enhanced lithium storage. Adv. Mater. 2013, 25, $2909-2914$. [CrossRef] [PubMed]

29. Xu, Y.; Sheng, K.; Li, C.; Shi, G. Self-assembled graphene hydrogel via a one-step hydrothermal process. ACS Nano 2010, 4, 4324-4330. [CrossRef] [PubMed]

30. Nguyen, D.D.; Tai, N.H.; Lee, S.B.; Kuo, W.S. Superhydrophobic and superoleophilic properties of graphene-based sponges fabricated using a facile dip coating method. Energy Environ. Sci. 2012, 5, 7908-7912. [CrossRef]

31. Worsley, M.A.; Pauzauskie, P.J.; Olson, T.Y.; Biener, J.; Satcher, J.H.; Baumann, T.F. Synthesis of graphene aerogel with high electrical conductivity. J. Am. Chem. Soc. 2010, 132, 14067-14069. [CrossRef] [PubMed]

32. Wang, Z.-L.; Xu, D.; Wang, H.-G.; Wu, Z.; Zhang, X.-B. In situ fabrication of porous graphene electrodes for high-performance energy storage. ACS Nano 2013, 7, 2422-2430. [CrossRef] [PubMed]

33. Ye, R.; Xiang, C.; Lin, J.; Peng, Z.; Huang, K.; Yan, Z.; Cook, N.P.; Samuel, E.L.G.; Hwang, C.-C.; Ruan, G.; et al. Coal as an abundant source of graphene quantum dots. Nat. Commun 2013, 4, 2943. [CrossRef] [PubMed]

34. Kosynkin, D.V.; Higginbotham, A.L.; Sinitskii, A.; Lomeda, J.R.; Dimiev, A.; Price, B.K.; Tour, J.M. Longitudinal unzipping of carbon nanotubes to form graphene nanoribbons. Nature 2009, 458, 872-876. [CrossRef] [PubMed]

35. Qiu, L.; Liu, J.Z.; Chang, S.L.Y.; Wu, Y.; Li, D. Biomimetic superelastic graphene-based cellular monoliths. Nat. Commun. 2012, 3, 1241. [CrossRef] [PubMed]

36. Li, L.L.; Wu, G.H.; Yang, G.H.; Peng, J.; Zhao, J.W.; Zhu, J.J. Focusing on luminescent graphene quantum dots: Current status and future perspectives. Nanoscale 2013, 5, 4015-4039. [CrossRef] [PubMed]

37. Sun, H.J.; Wu, L.; Wei, W.L.; Qu, X.G. Recent advances in graphene quantum dots for sensing. Mater. Today 2013, 16, 433-442. [CrossRef]

38. Shinde, D.B.; Pillai, V.K. Electrochemical preparation of luminescent graphene quantum dots from multiwalled carbon nanotubes. Chem. A Eur. J. 2012, 18, 12522-12528. [CrossRef] [PubMed]

39. Lin, L.; Zhang, S. Creating high yield water soluble luminescent graphene quantum dots via exfoliating and disintegrating carbon nanotubes and graphite flakes. Chem. Commun. 2012, 48, 10177-10179. [CrossRef] [PubMed]

40. Peng, J.; Gao, W.; Gupta, B.K.; Liu, Z.; Romero-Aburto, R.; Ge, L.; Song, L.; Alemany, L.B.; Zhan, X.; Gao, G.; et al. Graphene quantum dots derived from carbon fibers. Nano Lett. 2012, 12, 844-849. [CrossRef] [PubMed]

41. Yeh, T.-F.; Teng, C.-Y.; Chen, S.-J.; Teng, H. Nitrogen-doped graphene oxide quantum dots as photocatalysts for overall water-splitting under visible light illumination. Adv. Mater. 2014, 26, 3297-3303. [CrossRef] [PubMed]

42. Song, S.H.; Jang, M.-H.; Chung, J.; Jin, S.H.; Kim, B.H.; Hur, S.-H.; Yoo, S.; Cho, Y.-H.; Jeon, S. Highly efficient light-emitting diode of graphene quantum dots fabricated from graphite intercalation compounds. Adv. Opt. Mater. 2014, 2, 1016-1023. [CrossRef]

43. Ananthanarayanan, A.; Wang, X.; Routh, P.; Sana, B.; Lim, S.; Kim, D.-H.; Lim, K.-H.; Li, J.; Chen, P. Facile synthesis of graphene quantum dots from $3 \mathrm{D}$ graphene and their application for $\mathrm{Fe}^{3+}$ sensing. Adv. Funct. Mater. 2014, 24, 3021-3026. [CrossRef]

44. Ge, J.; Lan, M.; Zhou, B.; Liu, W.; Guo, L.; Wang, H.; Jia, Q.; Niu, G.; Huang, X.; Zhou, H.; et al. A graphene quantum dot photodynamic therapy agent with high singlet oxygen generation. Nat. Commun. 2014, 5, 4596. [CrossRef] [PubMed]

45. Qin, H.; Gong, T.; Jin, Y.; Cho, Y.; Shin, C.; Lee, C.; Kim, T. Near-UV-emitting graphene quantum dots from graphene hydrogels. Carbon 2015, 94, 181-188. [CrossRef]

46. He, P.; Sun, J.; Tian, S.Y.; Yang, S.W.; Ding, S.J.; Ding, G.Q.; Xie, X.M.; Jiang, M.H. Processable aqueous dispersions of graphene stabilized by graphene quantum dots. Chem. Mater. 2015, 27, 218-226. [CrossRef]

47. Liu, Y.; Gao, B.; Qiao, Z.; Hu, Y.; Zheng, W.; Zhang, L.; Zhou, Y.; Ji, G.; Yang, G. Gram-scale synthesis of graphene quantum dots from single carbon atoms growth via energetic material deflagration. Chem. Mater. 2015, 27, 4319-4327. [CrossRef] 
48. Zhang, M.; Bai, L.; Shang, W.; Xie, W.; Ma, H.; Fu, Y.; Fang, D.; Sun, H.; Fan, L.; Han, M.; et al. Facile synthesis of water-soluble, highly fluorescent graphene quantum dots as a robust biological label for stem cells. J. Mater. Chem. 2012, 22, 7461-7467. [CrossRef]

49. Zhu, Z.; Ma, J.; Wang, Z.; Mu, C.; Fan, Z.; Du, L.; Bai, Y.; Fan, L.; Yan, H.; Phillips, D.L.; et al. Efficiency enhancement of perovskite solar cells through fast electron extraction: The role of graphene quantum dots. J. Am. Chem. Soc. 2014, 136, 3760-3763. [CrossRef] [PubMed]

50. Pan, D.; Zhang, J.; Li, Z.; Wu, M. Hydrothermal route for cutting graphene sheets into blue-luminescent graphene quantum dots. Adv. Mater. 2010, 22, 734-738. [CrossRef] [PubMed]

51. Zhu, S.; Zhang, J.; Qiao, C.; Tang, S.; Li, Y.; Yuan, W.; Li, B.; Tian, L.; Liu, F.; Hu, R.; et al. Strongly green-photoluminescent graphene quantum dots for bioimaging applications. Chem. Commun. 2011, 47, 6858-6860. [CrossRef] [PubMed]

52. Ju, J.; Chen, W. In situ growth of surfactant-free gold nanoparticles on nitrogen-doped graphene quantum dots for electrochemical detection of hydrogen peroxide in biological environments. Anal. Chem. 2015, 87, 1903-1910. [CrossRef] [PubMed]

53. Ponomarenko, L.A.; Schedin, F.; Katsnelson, M.I.; Yang, R.; Hill, E.W.; Novoselov, K.S.; Geim, A.K. Chaotic dirac billiard in graphene quantum dots. Science 2008, 320, 356-358. [CrossRef] [PubMed]

54. Lee, J.; Kim, K.; Park, W.I.; Kim, B.-H.; Park, J.H.; Kim, T.-H.; Bong, S.; Kim, C.-H.; Chae, G.; Jun, M.; et al. Uniform graphene quantum dots patterned from self-assembled silica nanodots. Nano Lett. 2012, 12, 6078-6083. [CrossRef] [PubMed]

55. Shen, J.; Zhu, Y.; Chen, C.; Yang, X.; Li, C. Facile preparation and upconversion luminescence of graphene quantum dots. Chem. Commun. 2011, 47, 2580-2582. [CrossRef] [PubMed]

56. Dong, Y.; Shao, J.; Chen, C.; Li, H.; Wang, R.; Chi, Y.; Lin, X.; Chen, G. Blue luminescent graphene quantum dots and graphene oxide prepared by tuning the carbonization degree of citric acid. Carbon 2012, 50, 4738-4743. [CrossRef]

57. Yan, X.; Cui, X.; Li, L.-S. Synthesis of large, stable colloidal graphene quantum dots with tunable size. J. Am. Chem. Soc. 2010, 132, 5944-5945. [CrossRef] [PubMed]

58. Yan, X.; Cui, X.; Li, B.; Li, L.-S. Large, solution-processable graphene quantum dots as light absorbers for photovoltaics. Nano Lett. 2010, 10, 1869-1873. [CrossRef] [PubMed]

59. Jiao, L.; Zhang, L.; Wang, X.; Diankov, G.; Dai, H. Narrow graphene nanoribbons from carbon nanotubes. Nature 2009, 458, 877-880. [CrossRef] [PubMed]

60. Cataldo, F.; Compagnini, G.; Patané, G.; Ursini, O.; Angelini, G.; Ribic, P.R.; Margaritondo, G.; Cricenti, A.; Palleschi, G.; Valentini, F. Graphene nanoribbons produced by the oxidative unzipping of single-wall carbon nanotubes. Carbon 2010, 48, 2596-2602. [CrossRef]

61. Kumar, P.; Panchakarla, L.S.; Rao, C.N.R. Laser-induced unzipping of carbon nanotubes to yield graphene nanoribbons. Nanoscale 2011, 3, 2127-2129. [CrossRef] [PubMed]

62. Castillo-Martinez, E.; Carretero-Gonzalez, J.; Sovich, J.; Lima, M.D. High temperature structural transformations of few layer graphene nanoribbons obtained by unzipping carbon nanotubes. J. Mater. Chem. A 2014, 2, 221-228. [CrossRef]

63. Wang, C.; Li, Y.-S.; Jiang, J.; Chiang, W.-H. Controllable tailoring graphene nanoribbons with tunable surface functionalities: An effective strategy toward high-performance lithium-ion batteries. ACS Appl. Mater. Interfaces 2015, 7, 17441-17449. [CrossRef] [PubMed]

64. Han, M.Y.; Özyilmaz, B.; Zhang, Y.; Kim, P. Energy band-gap engineering of graphene nanoribbons. Phys. Rev. Lett. 2007, 98, 206805. [CrossRef] [PubMed]

65. Bai, J.; Duan, X.; Huang, Y. Rational fabrication of graphene nanoribbons using a nanowire etch mask. Nano Lett. 2009, 9, 2083-2087. [CrossRef] [PubMed]

66. Campos, L.C.; Manfrinato, V.R.; Sanchez-Yamagishi, J.D.; Kong, J.; Jarillo-Herrero, P. Anisotropic etching and nanoribbon formation in single-layer graphene. Nano Lett. 2009, 9, 2600-2604. [CrossRef] [PubMed]

67. Li, X.; Wang, X.; Zhang, L.; Lee, S.; Dai, H. Chemically derived, ultrasmooth graphene nanoribbon semiconductors. Science 2008, 319, 1229-1232. [CrossRef] [PubMed]

68. Mohanty, N.; Moore, D.; Xu, Z.; Sreeprasad, T.S.; Nagaraja, A.; Rodriguez, A.A.; Berry, V. Nanotomy-based production of transferable and dispersible graphene nanostructures of controlled shape and size. Nat. Commun. 2012, 3, 844. [CrossRef] [PubMed] 
69. Elías, A.L.; Botello-Méndez, A.R.; Meneses-Rodríguez, D.; Jehová González, V.; Ramírez-González, D.; Ci, L.; Muñoz-Sandoval, E.; Ajayan, P.M.; Terrones, H.; Terrones, M. Longitudinal cutting of pure and doped carbon nanotubes to form graphitic nanoribbons using metal clusters as nanoscalpels. Nano Lett. 2010, 10, 366-372. [CrossRef] [PubMed]

70. Parashar, U.K.; Bhandari, S.; Srivastava, R.K.; Jariwala, D.; Srivastava, A. Single step synthesis of graphene nanoribbons by catalyst particle size dependent cutting of multiwalled carbon nanotubes. Nanoscale 2011, 3, 3876-3882. [CrossRef] [PubMed]

71. Cano-Márquez, A.G.; Rodríguez-Macías, F.J.; Campos-Delgado, J.; Espinosa-González, C.G.; Tristán-López, F.; Ramírez-González, D.; Cullen, D.A.; Smith, D.J.; Terrones, M.; Vega-Cantú, Y.I. Ex-MWNTs: Graphene sheets and ribbons produced by lithium intercalation and exfoliation of carbon nanotubes. Nano Lett. 2009, 9, 1527-1533. [CrossRef] [PubMed]

72. Kosynkin, D.V.; Lu, W.; Sinitskii, A.; Pera, G.; Sun, Z.; Tour, J.M. Highly conductive graphene nanoribbons by longitudinal splitting of carbon nanotubes using potassium vapor. ACS Nano 2011, 5, 968-974. [CrossRef] [PubMed]

73. Genorio, B.; Lu, W.; Dimiev, A.M.; Zhu, Y.; Raji, A.-R.O.; Novosel, B.; Alemany, L.B.; Tour, J.M. In situ intercalation replacement and selective functionalization of graphene nanoribbon stacks. ACS Nano 2012, 6, 4231-4240. [CrossRef] [PubMed]

74. Talirz, L.; Söde, H.; Cai, J.; Ruffieux, P.; Blankenburg, S.; Jafaar, R.; Berger, R.; Feng, X.; Müllen, K.; Passerone, D.; et al. Termini of bottom-up fabricated graphene nanoribbons. J. Am. Chem. Soc. 2013, 135, 2060-2063. [CrossRef] [PubMed]

75. Vo, T.H.; Shekhirev, M.; Kunkel, D.A.; Morton, M.D.; Berglund, E.; Kong, L.; Wilson, P.M.; Dowben, P.A.; Enders, A.; Sinitskii, A. Large-scale solution synthesis of narrow graphene nanoribbons. Nat. Commun. 2014, 5, 3189. [CrossRef] [PubMed]

76. Wei, D.; Liu, Y.; Zhang, H.; Huang, L.; Wu, B.; Chen, J.; Yu, G. Scalable synthesis of few-layer graphene ribbons with controlled morphologies by a template method and their applications in nanoelectromechanical switches. J. Am. Chem. Soc. 2009, 131, 11147-11154. [CrossRef] [PubMed]

77. Sprinkle, M.; Ruan, M.; Hu, Y.; Hankinson, J.; Rubio Roy, M.; Zhang, B.; Wu, X.; Berger, C.; de Heer, W.A. Scalable templated growth of graphene nanoribbons on sic. Nat. Nano 2010, 5, 727-731. [CrossRef] [PubMed]

78. Patil, U.; Lee, S.C.; Kulkarni, S.; Sohn, J.S.; Nam, M.S.; Han, S.; Jun, S.C. Nanostructured pseudocapacitive materials decorated 3D graphene foam electrodes for next generation supercapacitors. Nanoscale 2015, 7, 6999-7021. [CrossRef] [PubMed]

79. Fang, Q.; Shen, Y.; Chen, B. Synthesis, decoration and properties of three-dimensional graphene-based macrostructures: A review. Chem. Eng. J. 2015, 264, 753-771. [CrossRef]

80. Ma, Y.; Chen, Y. Three-dimensional graphene networks: Synthesis, properties and applications. Natl. Sci. Rev. 2015, 2, 40-53. [CrossRef]

81. Mao, S.; Lu, G.; Chen, J. Three-dimensional graphene-based composites for energy applications. Nanoscale 2015, 7, 6924-6943. [CrossRef] [PubMed]

82. Xu, Y.; Shi, G.; Duan, X. Self-assembled three-dimensional graphene macrostructures: Synthesis and applications in supercapacitors. Acc. Chem. Res. 2015, 48, 1666-1675. [CrossRef] [PubMed]

83. Yan, Z.; Yao, W.; Hu, L.; Liu, D.; Wang, C.; Lee, C.-S. Progress in the preparation and application of three-dimensional graphene-based porous nanocomposites. Nanoscale 2015, 7, 5563-5577. [CrossRef] [PubMed]

84. Chen, W.; Li, S.; Chen, C.; Yan, L. Self-assembly and embedding of nanoparticles by in situ reduced graphene for preparation of a 3D graphene/nanoparticle aerogel. Adv. Mater. 2011, 23, 5679-5683. [CrossRef] [PubMed]

85. Sheng, K.; Sun, Y.; Li, C.; Yuan, W.; Shi, G. Ultrahigh-rate supercapacitors based on eletrochemically reduced graphene oxide for ac line-filtering. Sci. Rep. 2012, 2, 247. [CrossRef] [PubMed]

86. Cong, H.-P.; Ren, X.-C.; Wang, P.; Yu, S.-H. Macroscopic multifunctional graphene-based hydrogels and aerogels by a metal ion induced self-assembly process. ACS Nano 2012, 6, 2693-2703. [CrossRef] [PubMed]

87. Liu, F.; Seo, T.S. A controllable self-assembly method for large-scale synthesis of graphene sponges and free-standing graphene films. Adv. Funct. Mater. 2010, 20, 1930-1936. [CrossRef]

88. Choi, B.G.; Yang, M.; Hong, W.H.; Choi, J.W.; Huh, Y.S. 3D macroporous graphene frameworks for supercapacitors with high energy and power densities. ACS Nano 2012, 6, 4020-4028. [CrossRef] [PubMed] 
89. Wang, H.; Wang, G.; Ling, Y.; Qian, F.; Song, Y.; Lu, X.; Chen, S.; Tong, Y.; Li, Y. High power density microbial fuel cell with flexible 3D graphene-nickel foam as anode. Nanoscale 2013, 5, 10283-10290. [CrossRef] [PubMed]

90. Song, W.L.; Song, K.; Fan, L.Z. A versatile strategy toward binary three-dimensional architectures based on engineering graphene aerogels with porous carbon fabrics for supercapacitors. ACS Appl. Mater. Interfaces 2015, 7, 4257-4264. [CrossRef] [PubMed]

91. Cao, X.; Shi, Y.; Shi, W.; Lu, G.; Huang, X.; Yan, Q.; Zhang, Q.; Zhang, H. Preparation of novel 3D graphene networks for supercapacitor applications. Small 2011, 7, 3163-3168. [CrossRef] [PubMed]

92. Chen, Z.; Ren, W.; Gao, L.; Liu, B.; Pei, S.; Cheng, H.-M. Three-dimensional flexible and conductive interconnected graphene networks grown by chemical vapour deposition. Nat. Mater. 2011, 10, 424-428. [CrossRef] [PubMed]

93. Dong, X.; Wang, X.; Wang, J.; Song, H.; Li, X.; Wang, L.; Chan-Park, M.B.; Li, C.M.; Chen, P. Synthesis of a $\mathrm{MnO}_{2}$-graphene foam hybrid with controlled $\mathrm{MnO}_{2}$ particle shape and its use as a supercapacitor electrode. Carbon 2012, 50, 4865-4870. [CrossRef]

94. Ito, Y.; Tanabe, Y.; Qiu, H.J.; Sugawara, K.; Heguri, S.; Tu, N.H.; Huynh, K.K.; Fujita, T.; Takahashi, T.; Tanigaki, K. High-quality three-dimensional nanoporous graphene. Angew. Chem. Int. Ed. 2014, 53, 4822-4826. [CrossRef] [PubMed]

95. Li, W.; Gao, S.; Wu, L.; Qiu, S.; Guo, Y.; Geng, X.; Chen, M.; Liao, S.; Zhu, C.; Gong, Y.; et al. High-density three-dimension graphene macroscopic objects for high-capacity removal of heavy metal ions. Sci. Rep. 2013, 3, 2125. [CrossRef] [PubMed]

96. Zhou, M.; Lin, T.; Huang, F.; Zhong, Y.; Wang, Z.; Tang, Y.; Bi, H.; Wan, D.; Lin, J. Highly conductive porous graphene/ceramic composites for heat transfer and thermal energy storage. Adv. Funct. Mater. 2013, 23, 2263-2269. [CrossRef]

97. Mecklenburg, M.; Schuchardt, A.; Mishra, Y.K.; Kaps, S.; Adelung, R.; Lotnyk, A.; Kienle, L.; Schulte, K. Aerographite: Ultra lightweight, flexible nanowall, carbon microtube material with outstanding mechanical performance. Adv. Mater. 2012, 24, 3486-3490. [CrossRef] [PubMed]

98. Xiao, X.; Beechem, T.E.; Brumbach, M.T.; Lambert, T.N.; Davis, D.J.; Michael, J.R.; Washburn, C.M.; Wang, J.; Brozik, S.M.; Wheeler, D.R.; et al. Lithographically defined three-dimensional graphene structures. ACS Nano 2012, 6, 3573-3579. [CrossRef] [PubMed]

99. Yoon, J.-C.; Lee, J.-S.; Kim, S.-I.; Kim, K.-H.; Jang, J.-H. Three-dimensional graphene nano-networks with high quality and mass production capability via precursor-assisted chemical vapor deposition. Sci. Rep. 2013, 3, 1788. [CrossRef]

100. Li, Y.; Zhao, Y.; Cheng, H.; Hu, Y.; Shi, G.; Dai, L.; Qu, L. Nitrogen-doped graphene quantum dots with oxygen-rich functional groups. J. Am. Chem. Soc. 2012, 134, 15-18. [CrossRef] [PubMed]

101. Deming, C.P.; Mercado, R.; Gadiraju, V.; Sweeney, S.W.; Khan, M.; Chen, S. Graphene quantum dots-supported palladium nanoparticles for efficient electrocatalytic reduction of oxygen in alkaline media. ACS Sustain. Chem. Eng. 2015, 3, 3315-3323. [CrossRef]

102. Chun, K.-Y.; Lee, H.S.; Lee, C.J. Nitrogen doping effects on the structure behavior and the field emission performance of double-walled carbon nanotubes. Carbon 2009, 47, 169-177. [CrossRef]

103. Li, Q.; Zhang, S.; Dai, L.; Li, L.-S. Nitrogen-doped colloidal graphene quantum dots and their size-dependent electrocatalytic activity for the oxygen reduction reaction. J. Am. Chem. Soc. 2012, 134, 18932-18935. [CrossRef] [PubMed]

104. Liu, Y.; Wu, P. Graphene quantum dot hybrids as efficient metal-free electrocatalyst for the oxygen reduction reaction. ACS Appl. Mater. Interfaces 2013, 5, 3362-3369. [CrossRef] [PubMed]

105. Saidi, W.A. Oxygen reduction electrocatalysis using N-doped graphene quantum-dots. J. Phys. Chem. Lett. 2013, 4, 4160-4165. [CrossRef]

106. Fei, H.; Ye, R.; Ye, G.; Gong, Y.; Peng, Z.; Fan, X.; Samuel, E.L.G.; Ajayan, P.M.; Tour, J.M. Boron- and nitrogen-doped graphene quantum dots/graphene hybrid nanoplatelets as efficient electrocatalysts for oxygen reduction. ACS Nano 2014, 8, 10837-10843. [CrossRef] [PubMed]

107. Favaro, M.; Ferrighi, L.; Fazio, G.; Colazzo, L.; Di Valentin, C.; Durante, C.; Sedona, F.; Gennaro, A.; Agnoli, S.; Granozzi, G. Single and multiple doping in graphene quantum dots: Unraveling the origin of selectivity in the oxygen reduction reaction. ACS Catal. 2015, 5, 129-144. [CrossRef] 
108. Fan, M.; Zhu, C.; Yang, J.; Sun, D. Facile self-assembly N-doped graphene quantum dots/graphene for oxygen reduction reaction. Electrochim. Acta 2016, 216, 102-109. [CrossRef]

109. Wang, M.; Fang, Z.; Zhang, K.; Fang, J.; Qin, F.; Zhang, Z.; Li, J.; Liu, Y.; Lai, Y. Synergistically enhanced activity of graphene quantum dots/graphene hydrogel composites: A novel all-carbon hybrid electrocatalyst for metal/air batteries. Nanoscale 2016, 8, 11398-11402. [CrossRef] [PubMed]

110. Liu, M.; Song, Y.; He, S.; Tjiu, W.W.; Pan, J.; Xia, Y.-Y.; Liu, T. Nitrogen-doped graphene nanoribbons as efficient metal-free electrocatalysts for oxygen reduction. ACS Appl. Mater. Interfaces 2014, 6, 4214-4222. [CrossRef] [PubMed]

111. Kim, H.; Lee, K.; Woo, S.I.; Jung, Y. On the mechanism of enhanced oxygen reduction reaction in nitrogen-doped graphene nanoribbons. Phys. Chem. Chem. Phys. 2011, 13, 17505-17510. [CrossRef] [PubMed]

112. Wang, C.; Li, H.; Zhao, J.; Zhu, Y.; Yuan, W.Z.; Zhang, Y. Graphene nanoribbons as a novel support material for high performance fuel cell electrocatalysts. Int. J. Hydrog. Energy 2013, 38, 13230-13237. [CrossRef]

113. Davis, D.J.; Raji, A.-R.O.; Lambert, T.N.; Vigil, J.A.; Li, L.; Nan, K.; Tour, J.M. Silver-graphene nanoribbon composite catalyst for the oxygen reduction reaction in alkaline electrolyte. Electroanal 2014, 26, 164-170. [CrossRef]

114. Xiao, B.B.; Lang, X.Y.; Jiang, Q. Pt monatomic wire supported on graphene nanoribbon for oxygen reduction reaction. RSC. Adv. 2014, 4, 28400-28408. [CrossRef]

115. Fan, X.; Peng, Z.; Ye, R.; Zhou, H.; Guo, X. M ${ }_{3} \mathrm{C}$ (M: Fe, Co, Ni) nanocrystals encased in graphene nanoribbons: An active and stable bifunctional electrocatalyst for oxygen reduction and hydrogen evolution reactions. ACS Nano 2015, 9, 7407-7418. [CrossRef] [PubMed]

116. Gong, Y.; Fei, H.; Zou, X.; Zhou, W.; Yang, S.; Ye, G.; Liu, Z.; Peng, Z.; Lou, J.; Vajtai, R.; et al. Boron- and nitrogen-substituted graphene nanoribbons as efficient catalysts for oxygen reduction reaction. Chem. Mater. 2015, 27, 1181-1186. [CrossRef]

117. Jin, H.; Huang, H.; He, Y.; Feng, X.; Wang, S.; Dai, L.; Wang, J. Graphene quantum dots supported by graphene nanoribbons with ultrahigh electrocatalytic performance for oxygen reduction. J. Am. Chem. Soc. 2015, 137, 7588-7591. [CrossRef] [PubMed]

118. Lu, X.; Chan, H.M.; Sun, C.-L.; Tseng, C.-M.; Zhao, C. Interconnected core-shell carbon nanotube-graphene nanoribbon scaffolds for anchoring cobalt oxides as bifunctional electrocatalysts for oxygen evolution and reduction. J. Mater. Chem. A 2015, 3, 13371-13376. [CrossRef]

119. Wang, X.; Li, X.; Zhang, L.; Yoon, Y.; Weber, P.K.; Wang, H.; Guo, J.; Dai, H. N-Doping of graphene through electrothermal reactions with ammonia. Science 2009, 324, 768-771. [CrossRef] [PubMed]

120. Wang, X.; Sun, G.; Chen, P. Three-dimensional porous architectures of carbon nanotubes and graphene sheets for energy applications. Front. Energy Res. 2014, 2. [CrossRef]

121. Wang, H.; Yuan, X.; Zeng, G.; Wu, Y.; Liu, Y.; Jiang, Q.; Gu, S. Three dimensional graphene based materials: Synthesis and applications from energy storage and conversion to electrochemical sensor and environmental remediation. Adv. Colloid Interfaces 2015, 221, 41-59. [CrossRef] [PubMed]

122. Qiu, H.-J.; Liu, L.; Wang, Y. Template-directed fabrication of 3D graphene-based composite and their electrochemical energy-related applications. Sci. Bull. 2016, 61, 443-450. [CrossRef]

123. Wang, L.; Sofer, Z.; Ambrosi, A.; Šimek, P.; Pumera, M. 3D-graphene for electrocatalysis of oxygen reduction reaction: Increasing number of layers increases the catalytic effect. Electrochem. Commun. 2014, 46, 148-151. [CrossRef]

124. Liang, J.; Jiao, Y.; Jaroniec, M.; Qiao, S.Z. Sulfur and nitrogen dual-doped mesoporous graphene electrocatalyst for oxygen reduction with synergistically enhanced performance. Angew. Chem. Int. Ed. 2012, 51, 11496-11500. [CrossRef] [PubMed]

125. Zhao, Y.; Hu, C.; Song, L.; Wang, L.; Shi, G.; Dai, L.; Qu, L. Functional graphene nanomesh foam. Energy Environ. Sci. 2014, 7, 1913-1918. [CrossRef]

126. Tong, X.; Chen, S.; Guo, C.; Xia, X.; Guo, X.-Y. Mesoporous $\mathrm{NiCo}_{2} \mathrm{O}_{4}$ nanoplates on three-dimensional graphene foam as an efficient electrocatalyst for the oxygen reduction reaction. ACS Appl. Mater. Interfaces 2016, 8, 28274-28282. [CrossRef] [PubMed]

127. Jin, Z.; Nie, H.; Yang, Z.; Zhang, J.; Liu, Z.; Xu, X.; Huang, S. Metal-free selenium doped carbon nanotube/graphene networks as a synergistically improved cathode catalyst for oxygen reduction reaction. Nanoscale 2012, 4, 6455-6460. [CrossRef] [PubMed] 
128. Wu, Z.-S.; Yang, S.; Sun, Y.; Parvez, K.; Feng, X.; Müllen, K. 3D nitrogen-doped graphene aerogel-supported $\mathrm{Fe}_{3} \mathrm{O}_{4}$ nanoparticles as efficient electrocatalysts for the oxygen reduction reaction. J. Am. Chem. Soc. 2012, 134, 9082-9085. [CrossRef] [PubMed]

129. Zhao, Y.; Hu, C.; Hu, Y.; Cheng, H.; Shi, G.; Qu, L. A versatile, ultralight, nitrogen-doped graphene framework. Angew. Chem. 2012, 124, 11533-11537. [CrossRef]

130. Fu, X.; Jin, J.; Liu, Y.; Liu, Q.; Niu, K.; Zhang, J.; Cao, X. Graphene-xerogel-based non-precious metal catalyst for oxygen reduction reaction. Electrochem. Commun. 2013, 28, 5-8. [CrossRef]

131. Liang, J.; Du, X.; Gibson, C.; Du, X.W.; Qiao, S.Z. N-Doped graphene natively grown on hierarchical ordered porous carbon for enhanced oxygen reduction. Adv. Mater. 2013, 25, 6226-6231. [CrossRef] [PubMed]

132. Lin, Z.; Waller, G.H.; Liu, Y.; Liu, M.; Wong, C.-P. 3D nitrogen-doped graphene prepared by pyrolysis of graphene oxide with polypyrrole for electrocatalysis of oxygen reduction reaction. Nano Energy 2013, 2, 241-248. [CrossRef]

133. Lin, Z.; Waller, G.H.; Liu, Y.; Liu, M.; Wong, C.-P. Simple preparation of nanoporous few-layer nitrogen-doped graphene for use as an efficient electrocatalyst for oxygen reduction and oxygen evolution reactions. Carbon 2013, 53, 130-136. [CrossRef]

134. Xue, Y.; Yu, D.; Dai, L.; Wang, R.; Li, D.; Roy, A.; Lu, F.; Chen, H.; Liu, Y.; Qu, J. Three-dimensional B,N-doped graphene foam as a metal-free catalyst for oxygen reduction reaction. Phys. Chem. Chem. Phys. 2013, 15, 12220-12226. [CrossRef] [PubMed]

135. Bikkarolla, S.K.; Yu, F.; Zhou, W.; Joseph, P.; Cumpson, P.; Papakonstantinou, P. A three-dimensional $\mathrm{Mn}_{3} \mathrm{O}_{4}$ network supported on a nitrogenated graphene electrocatalyst for efficient oxygen reduction reaction in alkaline media. J. Mater. Chem. A 2014, 2, 14493-14501. [CrossRef]

136. Chen, L.; Cui, X.; Wang, Y.; Wang, M.; Qiu, R.; Shu, Z.; Zhang, L.; Hua, Z.; Cui, F.; Wei, C.; et al. One-step synthesis of sulfur doped graphene foam for oxygen reduction reactions. Dalton Trans. 2014, 43, 3420-3423. [CrossRef] [PubMed]

137. Liu, J.; Takeshi, D.; Orejon, D.; Sasaki, K.; Lyth, S.M. Defective nitrogen-doped graphene foam: A metal-free, non-precious electrocatalyst for the oxygen reduction reaction in acid. J. Electrochem. Soc. 2014, 161, F544-F550. [CrossRef]

138. Liu, J.; Takeshi, D.; Sasaki, K.; Lyth, S.M. Platinum-decorated nitrogen-doped graphene foam electrocatalysts. Fuel Cells 2014, 14, 728-734. [CrossRef]

139. Qin, Y.; Li, J.; Yuan, J.; Kong, Y.; Tao, Y.; Lin, F.; Li, S. Hollow mesoporous carbon nitride nanosphere/three-dimensional graphene composite as high efficient electrocatalyst for oxygen reduction reaction. J. Power Sources 2014, 272, 696-702. [CrossRef]

140. Yin, H.; Zhang, C.; Liu, F.; Hou, Y. Hybrid of iron nitride and nitrogen-doped graphene aerogel as synergistic catalyst for oxygen reduction reaction. Adv. Funct. Mater. 2014, 24, 2930-2937. [CrossRef]

141. Yuan, W.; Li, J.; Wang, L.; Chen, P.; Xie, A.; Shen, Y. Nanocomposite of N-doped $\mathrm{TiO}_{2}$ nanorods and graphene as an effective electrocatalyst for the oxygen reduction reaction. ACS Appl. Mater. Interfaces 2014, 6, 21978-21985. [CrossRef] [PubMed]

142. Chen, R.; Yan, J.; Liu, Y.; Li, J. Three-dimensional nitrogen-doped graphene/MnO nanoparticle hybrids as a high-performance catalyst for oxygen reduction reaction. J. Phys. Chem. C 2015, 119, 8032-8037. [CrossRef]

143. Cheng, J.; Li, Y.; Huang, X.; Wang, Q.; Mei, A.; Shen, P.K. Highly stable electrocatalysts supported on nitrogen-self-doped three-dimensional graphene-like networks with hierarchical porous structures. J. Mater. Chem. A 2015, 3, 1492-1497. [CrossRef]

144. Huang, Q.; Tao, F.; Zou, L.; Yuan, T.; Zou, Z.; Zhang, H.; Zhang, X.; Yang, H. One-step synthesis of Pt nanoparticles highly loaded on graphene aerogel as durable oxygen reduction electrocatalyst. Electrochim. Acta 2015, 152, 140-145. [CrossRef]

145. Wang, M.; Wang, J.; Hou, Y.; Shi, D.; Wexler, D.; Poynton, S.D.; Slade, R.C.T.; Zhang, W.; Liu, H.; Chen, J. $\mathrm{N}$-Doped crumpled graphene derived from vapor phase deposition of PPy on graphene aerogel as an efficient oxygen reduction reaction electrocatalyst. ACS Appl. Mater. Interfaces 2015, 7, 7066-7072. [CrossRef] [PubMed]

146. Wang, Z.; Cao, X.; Ping, J.; Wang, Y.; Lin, T.; Huang, X.; Ma, Q.; Wang, F.; He, C.; Zhang, H. Electrochemical doping of three-dimensional graphene networks used as efficient electrocatalysts for oxygen reduction reaction. Nanoscale 2015, 7, 9394-9398. [CrossRef] [PubMed] 
147. Xu, C.; Su, Y.; Liu, D.; He, X. Three-dimensional N,B-doped graphene aerogel as a synergistically enhanced metal-free catalyst for the oxygen reduction reaction. Phys. Chem. Chem. Phys. 2015, 17, 25440-25448. [CrossRef] [PubMed]

148. Ye, D.; Wang, L.; Zhang, R.; Liu, B.; Wang, Y.; Kong, J. Facile preparation of N-doped mesocellular graphene foam from sludge flocs for highly efficient oxygen reduction reaction. J. Mater. Chem. A 2015, 3, 15171-15176. [CrossRef]

149. Yun, S.; Lee, S.; Shin, C.; Park, S.; Kwon, S.J.; Park, H.S. One-pot self-assembled, reduced graphene oxide/palladium nanoparticle hybrid aerogels for electrocatalytic applications. Electrochim. Acta 2015, 180, 902-908. [CrossRef]

150. Zhou, X.; Bai, Z.; Wu, M.; Qiao, J.; Chen, Z. 3-Dimensional porous N-doped graphene foam as a non-precious catalyst for the oxygen reduction reaction. J. Mater. Chem. A 2015, 3, 3343-3350. [CrossRef]

151. Zhou, Y.; Yen, C.H.; Fu, S.; Yang, G.; Zhu, C.; Du, D.; Wo, P.C.; Cheng, X.; Yang, J.; Wai, C.M.; et al. One-pot synthesis of B-doped three-dimensional reduced graphene oxide via supercritical fluid for oxygen reduction reaction. Green Chem. 2015, 17, 3552-3560. [CrossRef]

152. Fu, X.; Choi, J.-Y.; Zamani, P.; Jiang, G.; Hoque, M.A.; Hassan, F.M.; Chen, Z. Co-n decorated hierarchically porous graphene aerogel for efficient oxygen reduction reaction in acid. ACS Appl. Mater. Interfaces 2016, 8, 6488-6495. [CrossRef] [PubMed]

153. Guo, W.; Ma, X.; Zhang, X.; Zhang, Y.; Yu, D.; He, X. Spinel CoMn ${ }_{2} \mathrm{O}_{4}$ nanoparticles supported on nitrogen and phosphorus dual doped graphene aerogel as efficient electrocatalysts for the oxygen reduction reaction. RSC Adv. 2016, 6, 96436-96444. [CrossRef]

154. Tang, S.; Zhou, X.; Xu, N.; Bai, Z.; Qiao, J.; Zhang, J. Template-free synthesis of three-dimensional nanoporous n-doped graphene for high performance fuel cell oxygen reduction reaction in alkaline media. Appl. Energy 2016, 175, 405-413. [CrossRef]

155. Wang, M.; Hou, Y.; Slade, R.C.T.; Wang, J.; Shi, D.; Wexler, D.; Liu, H.; Chen, J. Core-shell Co/CoO integrated on $3 \mathrm{D}$ nitrogen doped reduced graphene oxide aerogel as an enhanced electrocatalyst for the oxygen reduction reaction. Front. Chem. 2016, 4, 36. [CrossRef] [PubMed]

156. Wu, M.; Dou, Z.; Chang, J.; Cui, L. Nitrogen and sulfur Co-doped graphene aerogels as an efficient metal-free catalyst for oxygen reduction reaction in an alkaline solution. RSC Adv. 2016, 6, 22781-22790. [CrossRef]

157. Yan, W.; Cao, X.; Tian, J.; Jin, C.; Ke, K.; Yang, R. Nitrogen/sulfur dual-doped 3D reduced graphene oxide networks-supported $\mathrm{CoFe}_{2} \mathrm{O}_{4}$ with enhanced electrocatalytic activities for oxygen reduction and evolution reactions. Carbon 2016, 99, 195-202. [CrossRef]

158. Zhu, Z.; Yang, Y.; Guan, Y.; Xue, J.; Cui, L. Construction of a cobalt-embedded nitrogen-doped carbon material with the desired porosity derived from the confined growth of MOFs within graphene aerogels as a superior catalyst towards HER and ORR. J. Mater. Chem. A 2016, 4, 15536-15545. [CrossRef]

(C) 2016 by the authors; licensee MDPI, Basel, Switzerland. This article is an open access article distributed under the terms and conditions of the Creative Commons Attribution (CC-BY) license (http:/ / creativecommons.org/licenses/by/4.0/). 